\title{
NÍVEIS DE CÁLCIO E DE BORO NA SOLUÇÃO NUTRITIVA PARA OS CULTIVARES DE GIRASSOL IAC-URUGUAI E RUMBOSSOL-91
}

\section{MARCELA TRECENTI CAPOANI}

Engenheira Agrônoma

Orientador: Prof. Dr. ANTONIO ROQUE DECHEN

Dissertação apresentada à Escola Superior de Agricultura "Luiz de Queiroz", Universidade de São Paulo, para obtenção do título de Mestre em Agronomia, Área de Concentração: Solos e Nutrição de Plantas.

PIRACICABA

Estado de São Paulo - Brasil

Janeiro - 2001 
Dados Internacionais de Catalogação na Publicação (CIP) DIVISÃO DE BIBLIOTECA E DOCUMENTAÇÃO - Campus "Luiz de Queiroz"/USP

Capoani, Marcela Trecenti

Niveis de cálcio e de boro na solução nutritiva para os cultivares de girassol IACUruguai e Rumbossol-91 / Marcela Trecenti Capoani. - - Piracicaba, 2001.

60 p. il.

Dissertação (mestrado) - Escola Superior de Agricultura Luiz de Queiroz, 2001. Bibliografia.

1. Boro 2. Cálcio 3. Solução nutritiva 4. Dosagem 5. Estufa 6. Girassol I. Título

$\operatorname{CDD} 633.39$ 
À Deus por me guiar em tudo que faço, Agradeço.

Aos meus pais, Silvio e Angela, aos meus familiares, Mariella, Matheus, Valmir e Artur, pelo carinho, confiança e incentivo, Ofereço. 


\section{AGRADECIMENTOS}

Ao Prof. Dr. Antonio Roque Dechen pela dedicação e carinho na orientação do trabalho.

À Coordenação de Aperfeiçoamento de Pessoal de Nível Superior (CAPES) pelo apoio financeiro através da Bolsa concedida.

À Escola Superior de Agricultura "Luiz de Queiroz" que através do Curso de Pós-graduação em Solos e Nutrição de Plantas me possibilitou a oportunidade de treinamento.

Ao Prof. Dr. Quirino Augusto de Camargo Carmello e ao Prof. Dr. Francisco Antonio Monteiro pelo apoio, amizade e carinho.

À Drª . Maria Regina Ungaro - IAC - Campinas, pela doação das sementes e pelas opiniões apresentadas.

Às funcionárias do Setor de Nutrição Mineral de Plantas: Mirtes V. Sesso, Nivanda M. de Moura, Lourdes A. D. de González, Lúcia H. S. P. Forti, Ednéia C. S. Mondoni e Sueli M. A. C. Bovi, pela atenção, paciência, compreensão e carinho.

Aos colegas de Pós-graduação do setor de Nutrição Mineral de Plantas da ESALQ pela amizade e companheirismo, em especial à Gláucia R. Anti, Jonas Ruschel, Waldssmiler T. Mattos, Roberto Wagner C. Raposo, Walcylene L. M. Pereira e Linda Monica Premazzi.

Ao estagiário Dylnei Consolmagno Neto, aluno de graduação da Escola Superior de Agricultura "Luiz de Queiroz" pelo auxílio na condução do experimento na casa-devegetação.

À Ilana Urbano Bron, aluna de pós-graduação do setor de Fisiologia e Bioquímica de Plantas da Escola Superior de Agricultura "Luiz de Queiroz", pelo apoio na fase final do trabalho.

Ao Engenheiro Agrônomo Marcelo Alves pela colaboração nas análises estatísticas. 


\section{SUMÁRIO}

RESUMO $\quad$ Página

SUMMARY ............................. vi

1 INTRODUÇÃO $\ldots \ldots \ldots \ldots \ldots \ldots \ldots \ldots \ldots \ldots \ldots \ldots \ldots$

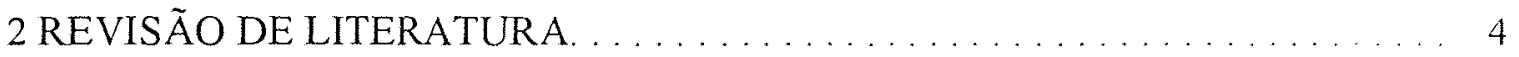

2.1 Aspectos gerais da cultura do girassol . . . . . . . . . . . . . . . . . 4

2.1.1 Nutrição mineral do girassol . . . . . . . . . . . . . . . . . . . 5

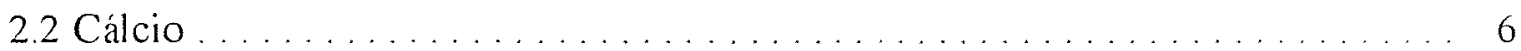

2.3 Boro . . . . . . . . . . . . . . . . . . . . . . . . . . 8

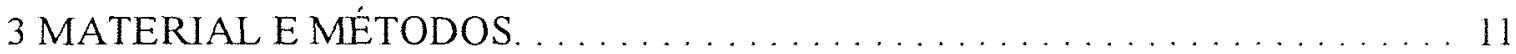

3.1 Condições experimentais. . . . . . . . . . . . . . . . 11

3.2 Delineamento experimental, tratamentos e condução do experimento. . . . . . . . . . . . . . . . . . . . . . .

3.3 Amostragens e determinações . . . . . . . . . . . . . . . 13

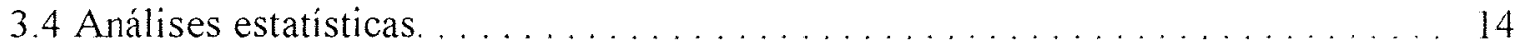

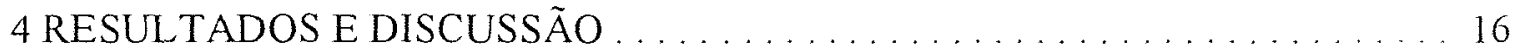

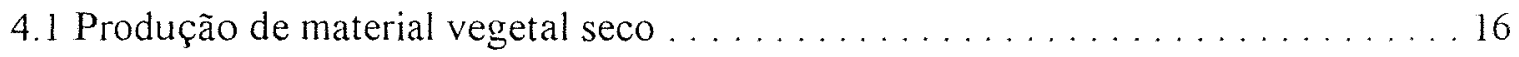

4.1.1 Altura e diâmetro dos caules das plantas. . . . . . . . . . . . . . . . 23

4.2 Sintomas visuais de deficiência. . . . . . . . . . . . . . . . . . . . . 26

4.3 Nutrientes . . . . . . . . . . . . . . . . . . . . . . . . . . . . . . . 29

4.3.1 Concentração e acúmulo de boro nas partes das plantas. . . . . . . . . . . . 31

4.3.2 Concentração e acúmulo de cálcio nas partes das plantas. . . . . . . . . . . . 40

4.4 Distribuição porcentual dos nutrientes acumulados nas partes das plantas . . . . 48

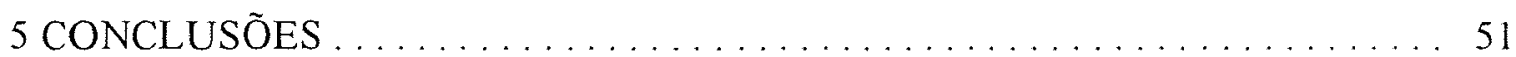

REFERÊNCIAS BIBLIOGRÁFICAS $\ldots \ldots \ldots \ldots \ldots \ldots \ldots \ldots \ldots \ldots$

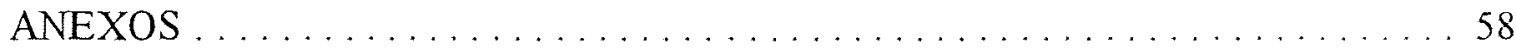




\section{NÍVEIS DE CÁlCIO E DE BORO NA SOLUÇÃO NUTRITIVA PARA OS \\ CULTIVARES DE GIRASSOL IAC-URUGUAI E RUMBOSSOL-91}

Autora: MARCELA TRECENTI CAPOANI

Orientador: Prof. Dr. ANTONIO ROQUE DECHEN

\section{RESUMO}

O girassol é uma das espécies mais sensiveis à deficiência de boro, e por essa razão, vem sendo utilizada em experimentos como planta teste para esse micronutriente. O objetivo do experimento foi estudar a interação entre doses de cálcio $(\mathrm{Ca})$ e de boro (B), fornecidas via solução nutritiva e, avaliar a influência das doses desses nutrientes na produção do material vegetal seco e na compartimentalização do cálcio e do boro na parte aérea das plantas. O experimento foi realizado em casa-de-vegetação utilizando-se os cultivares IAC-Uruguai e Rumbossol-91. Foram aplicados 12 tratamentos com duas doses de $\mathrm{B}\left(0,1\right.$ e $\left.0,5 \mathrm{mg} \mathrm{L}^{-1}\right)$ e seis de $\mathrm{Ca}\left(0,50,100,200,250\right.$ e $\left.300 \mathrm{mg} \mathrm{L}^{-1}\right)$. Foram cultivadas duas plantas por vaso, com capacidade para 3,6 litros, contendo sílica como substrato. O delineamento experimental foi o de blocos completos ao acaso em esquema fatorial $2 \times 6$ com quatro repetições. Aos 55 dias, avaliou-se a altura, diâmetro do caule, massa do material vegetal seco e os teores dos nutrientes no material vegetal seco nas seguintes partes das plantas: a) folhas do terço superior, b) folhas inferiores, c) terço superior do caule e d) caule inferior.

A manifestação de sintomas visuais de deficiência de boro foi mais intensa no cultivar IAC-Uruguai, no tratamento com $0,1 \mathrm{mg} \mathrm{L}^{-1}$ de $B$.

Os resultados permitiram concluir que houve interação significativa entre as doses de cálcio e boro na produção do material vegetal seco e no acúmulo desses nutrientes nas partes das plantas.

As folhas acumularam maiores quantidades de cálcio e boro do que os caules. Maiores produções de material vegetal seco foram verificadas nos tratamentos com 0,5 $m g \mathrm{~L}^{-1}$ de $\mathrm{B}$. O acúmulo de boro nas plantas foi influenciado pelas doses de cálcio fornecidas. 


\section{RATES OF CALCIUM AND BORON IN THE NUTRIENTE SOLUTION FOR \\ THE IAC-URUGUAI AND RUMBOSSOL-91 SUNFLOWER CULTIVARS \\ Author: MARCELA TRECENTI CAPOANI \\ Adviser: Prof. Dr. ANTONIO ROQUE DECHEN}

\section{SUMMARY}

The objective of this study was to evaluate the interaction between calcium and boron in the nutrient solution and the influence of these nutrients in the dry matter yield and in the calcium and boron compartmentation in the plants. The experiment was carried out with two sunflower cultivars grown under controlled conditions. Twelve combinations of these nutrients were applied in a $2 \times 6$ factorial with two boron rates $(0.1$ and $\left.0.5 \mathrm{mg} \mathrm{L}^{-1}\right)$ and six calcium rates $\left(0,50,100,200,250\right.$ and $\left.300 \mathrm{mg} \mathrm{L}^{-1}\right)$. Two plants were grown in pots with 3.6 liters containing ground quartz as substrate. The experimental was set in a randomized complete block design, with four replications. On the $55^{\text {th }}$ day, was evaluated the plant height, stem diameter, top part of plants dry matter yield, nutrient concentrations and nutrient accumulations into each sampled plant part: a) leaves in the upper one-third, b) lower leaves, c) stems in the upper one-third and d) lower stems.

The visual symptons of boron deficiency were more severe for the IAC-Uruguai cultivar when compared to Rumbossol-91, and they were observed only in the treatment with $0.1 \mathrm{mg} \mathrm{L}^{-1}$ of boron in the nutrient solution.

The results indicated that there was significant interaction betwen calcium and boron rates in the dry matter yield and in the accumulation of these nutrients in each plant part.

The leaves accumulated more quantities of calcium and boron than the stems. The highest dry matter yield was observed with $0.5 \mathrm{mg} \mathrm{L}^{-1}$ of $\mathrm{B}$. The rates of calcium had an influence on boron accumulation of plants. 


\section{INTRODUÇÃO}

O girassol é originário da América do Norte, podendo ser encontrado em estado selvagem desde as planícies do noroeste do Canadá até a América do Sul. O girassol pertence ao gênero Helianthus, família das Compostas. É um gênero complexo, compreendendo 49 espécies e 19 subespécies, sendo 12 espécies anuais e 37 perenes. É uma das quatro maiores culturas oleaginosas produtoras de óleo vegetal comestível em utilização no mundo (Ungaro, 2000).

A finalidade da produção do girassol é a elaboração do óleo comestível e o aproveitamento dos subprodutos da sua extração, tais como: tortas e farinhas para as rações balanceadas utilizadas na alimentação animal (Rossi, 1998). Ele pode ser utilizado como planta ornamental, medicinal, em rotação de culturas, adubação verde e como sementes "in natura" para pássaros (Silva, 1990). A planta verde de girassol pode ser utilizada na produção de silagem para a nutrição animal. Na elaboração de uma tonelada de semente para a extração do óleo, obtém-se em média $300 \mathrm{~kg}$ de torta e resíduos, o que representa uma importante fonte suplementar de proteínas para as rações animais. A composição química das tortas e do bagaço depende da qualidade das sementes e é muito parecida com a farinha de soja, sendo uma das mais ricas fontes de proteína (Vranceanu, 1977).

As numerosas tentativas para fazer do girassol uma cultura importante na agricultura brasileira, os esforços foram frustrados, pois a produtividade das lavouras era insatisfatória e o rendimento industrial muito baixo, devido ao baixo teor de óleo das sementes das variedades disponíveis, o que redundava em seguidas perdas de safra. 
Atualmente, estão sendo desenvolvidas novas variedades e híbridos mais produtivos e mais resistentes, ao mesmo tempo em que se executa um intenso programa de pesquisas para melhorar o manejo da adubação, das pragas e doenças da cultura.

Com isso, espera-se poder aumentar a produtividade média nacional, considerada ainda baixa $\left(1.000 \mathrm{~kg} \mathrm{ha}^{-1}\right)$, para patamares próximos da média Argentina $\left(1.800 \mathrm{~kg} \mathrm{ha}^{-1}\right)$, a qual é amplamente superada pelos bons produtores Argentinos, que chegam a colher até $3.000 \mathrm{~kg} \mathrm{ha}^{-1}$ (Agrianual, 1999).

Sendo o girassol uma cultura de importância mundial e relativamente pouco estudada, as informações sobre os distúrbios nutricionais são insuficientes (Blamey et al., 1984). Esse fator, associado à falta de material genético adaptado às condições tropicais, são os principais limitantes para o adequado cultivo em nosso país (Quaggio et al., 1991).

A mobilidade de redistribuição de um nutriente no interior da planta tem implicações fisiológicas importantes. Nutrientes imóveis, presentes nos tecidos maduros não se redistribuem para suprir as necessidades dos tecidos que estão em desenvolvimento, assim, devem estar disponíveis na solução do solo em todas as fases da cultura. Para nutrientes com mobilidade limitada no interior da planta, a ausência na solução do solo resulta em uma rápida inibição do crescimento das regiões meristemáticas. Essa șituação é crítica, principalmente para os nutrientes requeridos de forma contínua pelos tecidos em desenvolvimento, como é o caso do boro (Brown et al., 1999).

Devido à similaridade das funções que o boro e o cálcio exercem na constituição da parede celular e dos distúrbios causados por suas deficiências, o estudo conjunto desses dois nutrientes é sempre interessante. Não há, entretanto, menção de pesquisa sobre a ação interativa destes dois elementos, embora se encontre na literatura, estudos dos seus efeitos isolados (Santos et al., 1990).

O presente trabalho teve por objetivo estudar os efeitos de doses de cálcio e de boro e suas interações sobre as regiões de acúmulo desses nutrientes nas partes das plantas de girassol, cultivado em casa-de-vegetação. A escolha desses nutrientes deveu- 
se à grande importância deles no desenvolvimento do girassol e pelas semelhanças das deficiências desses nutrientes. 


\section{REVISÃO DE LITERATURA}

\subsection{Aspectos gerais da cultura do girassol}

O girassol é uma planta anual, com desenvolvimento vigoroso, seu sistema radicular possui grande capacidade de adaptação às condições de umidade do solo. É um cultivo econômico, rústico e que não requer maquinário especializado. Tem um ciclo vegetativo curto e adapta-se perfeitamente às condições de solo e clima pouco favoráveis.

Os solos mais adequados para essa cultura são os argilo-arenosos profundos, com boa fertilidade, permeáveis e com bom conteúdo de matéria orgânica. Os solos demasiadamente pesados, impermeáveis e os demasiado arenosos, com excesso de sal ou pedregosos, muito ácidos ou fortemente alcalinos, não são adequados para a cultura (Rossi, 1998).

O girassol adapta-se facilmente a condições de temperaturas variadas, podendo ser cultivado entre 13 e $30^{\circ} \mathrm{C}$, com retardamento na floração e na maturação quando as temperaturas constantes são mais baixas (Rossi, 1998).

Pode ser cultivado em todas as regiões do país, respeitando-se a época de semeadura mais adequada. Nas áreas produtoras de grãos, apresenta-se como uma opção nos sistemas de rotação e sucessão de culturas. O ciclo do girassol varia entre 90 e 130 dias, dependendo do cultivar e da época de semeadura.

A planta apresenta sistema radicular pivotante, o que lhe permite atingir camadas mais profundas do solo, e com isso explora um grande volume de solo e permite tolerar melhor os períodos de deficiência hídrica. $O$ caule é cilíndrico, 
geralmente não ramificado e na maioria dos cultivares comerciais pode atingir entre 1 e $3 \mathrm{~m}$ de altura.

A inflorescência é um capítulo cuja base é chamada de receptáculo, e sobre o qual estão as brácteas e flores. É uma planta de fecundação cruzada (alógama) em que a polinização é feita principalmente por insetos. Botanicamente, o fruto do girassol é denominado de aquênio, sendo formado por pericarpo (casca) e semente propriamente dita (amêndoa).

Para se obter altos rendimentos de girassol, é importante a escolha correta do cultivar. O conhecimento das diferentes variedades e dos híbridos disponíveis aos produtores é fundamental para uma difusão adequada da cultura.

\subsubsection{Nutrição mineral do girassol}

O girassol extrai grandes quantidades de nutrientes da solução do solo. Assim que a formação do capítulo e o aumento da massa vegetal se inicia, ocorre uma intensa migração dos nutrientes (nitrogênio, fósforo e potássio) da parte vegetativa para a parte reprodutiva da planta (Rossi, 1998).

É uma planta que se desenvolve bem em solos com fertilidade média; no entanto, altas produções só são obtidas em solos corrigidos quanto à acidez, férteis ou com boa fertilização suplementar (Ungaro, 2000).

O nitrogênio é um dos nutrientes mais exigidos pelo girassol, aumenta o conteúdo de proteína, mas pode reduzir a porcentagem de óleo das sementes, se aplicado em excesso. É componente estrutural de aminoácidos, amidas, alcalóides, vitaminas e da clorofila. A acumulação de nitrogênio é muito maior nas folhas do que no caule. Sua absorção é mais intensa no começo do ciclo vegetativo, portanto, é importante que a planta encontre esse nutriente em forma facilmente assimilável (Rossi, 1998).

O fósforo é importante no armazenamento e fornecimento de energia, na síntese de proteínas, tem função estrutural, atua na subdivisão celular, no desenvolvimento radicular, na germinação e na maturação das sementes (Malavolta, 1980; Rossi, 1998). 
A sua absorção é menos itensa, aumentando bastante no período de formação do capítulo e na floração (Rossi, 1998).

O potássio é absorvido em grandes quantidades pela cultura e apesar de não ter função estrutural no desenvolvimento da planta, facilita muito os processos fisiológicos, aumentando a resistência das plantas às adversidades climáticas.

O magnésio é componente da molécula de clorofila, é ativador de enzimas relacionadas ao metabolismo energético e ajuda no transporte do fósforo (Malavolta, 1980).

O enxofre é um nutriente muito importante, por ser componente essencial das proteínas vegetais, ajudando a manter a cor verde das folhas, o crescimento vigoroso e a formação de grãos.

Apesar de serem exigidos em pequenas quantidades, boro, cloro, cobre, ferro, manganês, molibdênio e zinco, são essenciais para a vida das plantas. A falta de um desses micronutrientes pode comprometer a produtividade da cultura. Segue-se abaixo maiores detalhes dos nutrientes estudados nesse trabalho.

\subsection{Cálcio}

Assim como o boro, o cálcio também apresenta baixa mobilidade nos tecidos das plantas. É absorvido pelas raízes como $\mathrm{Ca}^{+2}$, sendo a absorção reduzida por altas concentrações de $\mathrm{K}^{+} \mathrm{e} \mathrm{Mg}^{+2}$ no meio, como também por altas concentrações de $\mathrm{N}_{-} \mathrm{NH}_{4}{ }^{+}$. A maior parte do cálcio absorvido é transportada no xilema, embora parte dele possa fazê-lo pelo floema. O movimento ascendente se dá através de reações de sítios de troca com outros cátions como magnésio, manganês e zinco (Malavolta, 1980).

O conteúdo de cálcio da maioria das plantas superiores está na ordem de 5 a $30 \mathrm{mg} \mathrm{g}^{-1}$ de material vegetal seco. Este alto conteúdo de cálcio resulta de um alto nível de cálcio na solução do solo e também da eficiência do mecanismo de absorção do cálcio pelas células radiculares (Mengel \& Kirkby, 1987). A absorção do $\mathrm{Ca}^{++}$pode ser diminuída competitivamente, pela presença de outros cátions, tais como $\mathrm{K}^{+} \mathrm{e} \mathrm{NH}_{4}^{+}$, os quais são absorvidos rapidamente pelas raízes (Foster \& Mengel, 1969). 
O cálcio tem função estrutural pois é integrante da parede celular. O pectato de cálcio existente na lamela média é essencial para o fortalecimento da parede celular e dos tecidos das plantas. É um importante regulador osmótico e tem efetivo papel no balanço catiônico. É indispensável para a germinação do grão de pólen e crescimento do tubo polínico, o que pode ser atribuído ao seu papel na síntese da parede celular (Marschner, 1995).

Na planta, o cálcio caminha pelo simplasto ou apoplasto até a endoderme, onde atravessa as "Estrias de Caspary" ativamente, passando pelo simplasto e chegando aos vasos do xilema. No xilema, por fluxo de massa ou troca iônica com os radicais livres da parede do xilema, caminha até a parte aérea, chegando às folhas onde será metabolizado, tornando-se praticamente imóvel na planta (Malavolta, 1980; Marschner, 1995).

A falta do cálcio afeta, particularmente, os pontos de crescimento da raíz e devido ao seu papel na divisão celular, cessa o desenvolvimento e provoca necrose no tecido vegetal (Malavolta, 1980; Marschner, 1995).

No girassol, por ser cultivado principalmente em solos neutros ou alcalinos, é dificil o aparecimento da deficiência de cálcio nas condições de campo. O primeiro sintoma de deficiência desse nutriente é a redução na elongação do caule. A coloração das folhas fica mais escura, no entanto mais brilhante que as folhas supridas adequadamente com cálcio (Blamey et al., 1987).

Gupta (1972)' citado por Oyewole \& Aduayi (1992), reportou que a aplicação de calcário no solo reduziu a disponibilidade do boro para as plantas.

Segundo Penalosa et al. (1987) ${ }^{2}$, citados por Plese et al. (1998), a deficiência de boro acarreta diminuição no teor de cálcio da folha. Epstein (1975) citou que o cálcio exerce papel importante na disponibilidade do boro.

\footnotetext{
${ }^{1}$ Gupta, U. C. Interaction effects of boron and lime on barley. Science Soil Society of America Proceedings, v.36, p.332-334, 1972.

${ }^{2}$ Penalosa, J. M.; Zornoza, P.; Carpena, O. Estudios de las diferencias de boro y manganeso en plantas de tomate. Anales de Edafologia y Agrobiologia, v.56, p.749-758, 1987.
} 


\subsection{Boro}

O boro é absorvido da solução do solo preferencialmente como ácido bórico $\left(\mathrm{H}_{3} \mathrm{BO}_{3}\right)$. Segundo $\mathrm{Hu} \&$ Brown (1997), a absorção do boro é realizada por processo passivo e depende da concentração de $\mathrm{H}_{3} \mathrm{BO}_{3}$ contida na solução do solo, da permeabilidade da membrana, da formação de complexos internos e da taxa de transpiração.

A absorção de boro pelas plantas ocorre passivamente (não envolvendo gastos metabólicos) desde que a absorção não seja alterada por mudanças na temperatura, composição do sal ou pela adição de inibidores metabólicos (Seresinhe \& Oertli (1991)).

Furlani et al. (1990) concluiram que a eficiência de absorção e uso do boro, pode variar significativamente entre genótipos de girassol. Uma importante propriedade do ácido bórico que poderá influenciar na absorção do boro é sua capacidade de formar complexos com várias moléculas orgânicas (Hu \& Brown, 1997). Nessas moléculas, incluem-se açúcares, seus derivados (açúcares alcoólicos), fenóis, ácidos orgânicos, e alguns polímeros (Raven, 1980). Em trabalhos realizados com cereja (Apium graveolens), por $\mathrm{Hu} \&$ Brown (1997), o boro presente no floema apresentou-se completamente na forma complexada com manitol, e nenhuma forma livre de ácido bórico foi detectada. Segundo Brown \& Shelp (1997), em espécies de plantas que produzem quantidades significativas de açúcares alcóolicos, o boro é retranslocado como consequência da formação do complexo B-açúcares.

Segundo Brown \& Hu (1996), o boro incorporado na parede celular ou associado a componentes celulares torna-se imóvel. Segundo Brown \& Shelp (1997), o boro é o único nutriente que possui mobilidade restrita em muitas espécies de plantas. A falta de redistribuição do boro tem como consequências, os sintomas de carência que aparecem nos órgãos mais novos e regiões de crescimento, a necessidade de suprimento contínuo do nutriente e seu fornecimento deve ser realizado preferencialmente via radicular (Malavolta, 1980).

O boro é elemento essencial para o crescimento das plantas, embora suas funções primárias ainda não estejam claras. Há uma série de funções atribuídas ao boro: 
transporte de açúcares; síntese da parede celular; aumento do tamanho das células devido à formação de complexos entre o ácido bórico e os carboidratos; lignificação; integridade da parede celular; metabolismo de RNA (Marschner, 1995; Parr \& Loughman, 1983³ , citados por Cakmak \& Römheld, 1997). É muito importante na produção de sementes, e sua deficiência pode comprometer a produção.

O girassol é sensível à deficiência de boro, os sintomas dessa deficiência consistem de manchas foliares no começo da floração e algumas vezes, também antes, na pré-floração. As folhas passam a apresentar manchas necróticas, sendo também afetados os tecidos internos da parte superior do caule, prejudicando o desenvolvimento do capítulo em floração. Nesse ponto, o caule fica quebradiço, provocando a queda do capítulo. Segundo Marschner (1995), os sintomas de deficiência de boro nas regiões apicais ocorrem principalmente nos tecidos meristemáticos (brotos), enquanto que sintomas de toxidez ocorrem primeiramente nas margens de folhas maduras.

A busca de genótipos menos sensíveis à deficiência de boro ou mais eficientes na sua absorção e uso, pode ser uma alternativa viável no melhoramento da espécie.

Na maioria das espécies de plantas, a mobilidade de redistribuição do boro e os seus sintomas de deficiência e da toxicidade evidenciam restrições quanto à sua mobilidade (Brown \& Shelp, 1997). Este fenômeno pode alterar a maneira pela qual esse nutriente vem sendo manejado e permite a seleção de materiais genotipicamente resistentes à deficiência de boro. Nable (1988), estudando feijoeiro e trigo, observou que os cultivares resistentes à toxicidade de boro acumularam menos boro, quando comparados aos cultivares sensíveis.

Estudos realizados com boro demonstraram que os pontos de crescimento das plantas são exigentes nesse micronutriente, o qual juntamente com o cálcio, melhora o transporte de açúcares para o caule e os grãos, influindo na produção de sementes. A distribuição desse nutriente nas plantas não é uniforme, pois apresenta uma concentração maior nas folhas do que nos caules (Rossi, 1998). Segundo Reeve \& Shive (1944), a

\footnotetext{
${ }^{3}$ Parr, A.; Loughman, B. C. Boron and membrane function in plants. In: Robb, D. A.; Pierpoint, W. S. (Eds). Metal and Micronutrients, Uptake and Utilization by Plants. New York: Academic Press, 1983, p.87-107.
} 
semelhança entre os sintomas de deficiência de boro e de cálcio sugere que suas funções estejam intimamente associadas.

Segundo Ramon et al. (1990) ${ }^{4}$, citados por Plese et al. (1998), o boro afeta a translocação e a absorção de cálcio e potássio pela planta.

\footnotetext{
${ }^{4}$ Ramon, A. M.; Carpena-Ruiz, R. O.; Garate, A.; Beusichen M. L-van. The effects of short term deficiency of boron on potassium, calcium and magnesium distribuition in leaves and roots of tomato (Lycopersicon esculentum) plants. Developments in Plant and Soil Science, v.21, p.287-290, 1990.
} 


\section{MATERIAL E MÉTODOS}

\subsection{Condições experimentais}

O experimento foi conduzido na casa-de-vegetação, localizada no Departamento de Solos e Nutrição de Plantas da Escola Superior de Agricultura "Luiz de Queiroz", Piracicaba-SP (22 42' $03^{\circ}$ ' S, 47 $38^{\prime} 01^{\prime}$ ' W, 576m), entre os dias 08 de abril a 01 de junho de 2000. Os valores de temperatura, registrados na casa-de-vegetação, constam no anexo A.

A estrutura para o cultivo das plantas de girassol constou de uma casa-devegetação tipo capela, com laterais de alvenaria e janelas de vidro e com cobertura de vidro. As plantas foram cultivadas em vasos de plástico, com capacidade de 3,6 litros, com dreno na base para permitir o escoamento da solução nutritiva. Os vasos continham sílica para sustentação das plantas e foram dispostos na casa-de-vegetação sobre bancadas de aproximadamente 1,00 $\mathrm{m}$ de altura (Figura 1).

\subsection{Delineamento experimental, tratamentos e condução do experimento}

O experimento foi realizado utilizando-se o delineamento experimental de blocos completos ao acaso, em esquema fatorial $2 \times 6$ (duas doses de boro e seis doses de cálcio), com quatro repetições, totalizando 48 unidades experimentais com duas plantas por vaso. Utilizou-se dois genótipos de girassol (IAC-Uruguai e Rumbossol-91), totalizando 96 unidades experimentais.

A composição química da solução nutritiva foi baseada em Sarruge (1975), com diferentes doses de cálcio e boro nos tratamentos como na Tabela 1. 


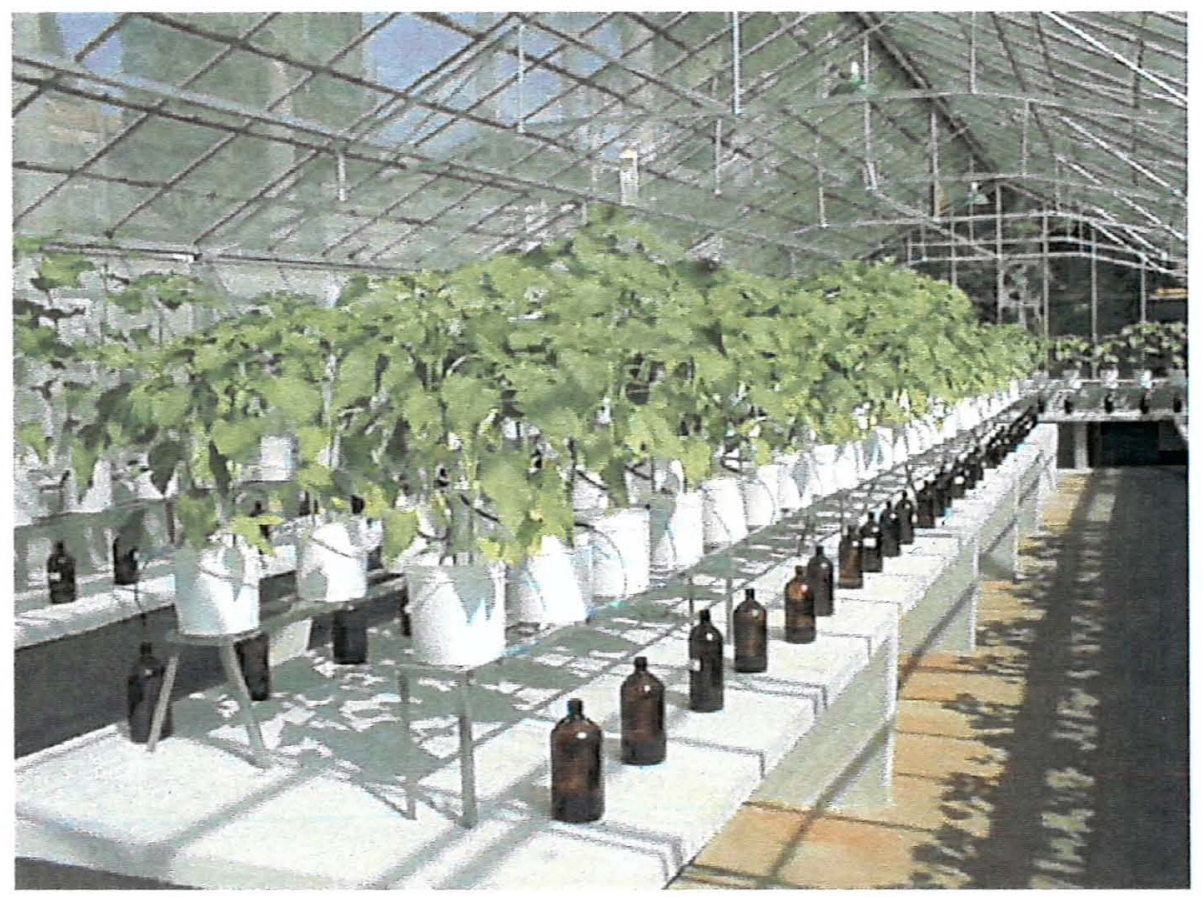

Figura 1 - Visão geral do experimento em casa-de-vegetação.

A semeadura foi realizada em 08 de abril de 2000 em bandejas plásticas, contendo areia lavada em água corrente e posteriormente com água deionizada. Irrigouse com água deionizada até o transplante e depois, com solução nutritiva, completa, diluída na proporção de 1:2, por um período de 15 dias. Após esse período, os tratamentos foram aplicados, fornecendo-se 1 litro de solução por vaso, sendo circuladas três vezes ao dia e renovadas a cada sete dias.

O transplante de quatro mudas para os vasos ocorreu 10 dias após a semeadura, quando as plantas apresentavam cerca de sete centímetros de altura. No dia 28 de abril realizou-se o desbaste de duas plantas, deixando-se somente duas plantas por vaso.

O controle de doenças foi efetuado de acordo com a necessidade. As aplicações de fungicida foram realizadas preventivamente nas paredes da casa-de-vegetação, as plantas não receberam aplicação direta. O controle da doença (oídio) foi realizado manualmente com a utilização de água e algodão logo após o aparecimento da doença. 
Tabela 1 - Volumes das soluções estoque utilizados no preparo das soluções nutritivas, balanceadas segundo Sarruge (1975).

\begin{tabular}{|c|c|c|c|c|c|c|c|c|c|c|c|c|}
\hline $\begin{array}{l}\text { Níveis Ca } \\
\left(\mathrm{mg} \mathrm{L}^{-1}\right)\end{array}$ & \multicolumn{2}{|c|}{0} & \multicolumn{4}{|c|}{$1,25 \mathrm{~mm}\left(\mathrm{c}^{-1100} 2.5\right.$} & \multicolumn{2}{|c|}{5,0} & \multicolumn{2}{|c|}{$\begin{array}{r}250 \\
6.25\end{array}$} & \multicolumn{2}{|c|}{7,50} \\
\hline $\begin{array}{l}\text { Níveis B } \\
\left(\mathrm{mg} \mathrm{L}^{-1}\right)\end{array}$ & 0,1 & 0,5 & 0,1 & 0,5 & 0,1 & 0,5 & 0,1 & 0,5 & 0,1 & 0,5 & 0,1 & 0,5 \\
\hline Tratamentos & $\mathrm{T} 1$ & $\mathrm{~T} 2$ & T3 & T4 & T5 & T6 & $\mathrm{T} 7$ & T8 & T9 & $\mathrm{T} 10$ & $\mathrm{~T} 11$ & $\mathrm{~T} 12$ \\
\hline & \multicolumn{12}{|c|}{$\mathrm{mL} \mathrm{L}^{-1}$} \\
\hline $\mathrm{KH}_{2} \mathrm{PO}_{4}$ & 1 & 1 & 1 & 1 & 1 & 1 & 1 & 1 & 1 & 1 & 1 & 1 \\
\hline $\mathrm{KNO}_{3}$ & 5,0 & 5,0 & 4,375 & 4,375 & 3,75 & 3,75 & 2,5 & 2,5 & 2,5 & 2,5 & 2,5 & 2,5 \\
\hline $\mathrm{Ca}\left(\mathrm{NO}_{3}\right)_{2}$ & - & - & 1,25 & 1,25 & 2,5 & 2,5 & 5,0 & 5,0 & 5,0 & 5,0 & 5,0 & 5,0 \\
\hline $\mathrm{MgSO}_{4}$ & 2 & 2 & 2 & 2 & 2 & 2 & 2 & 2 & 2 & 2 & 2 & 2 \\
\hline $\mathrm{NH}_{4} \mathrm{NO}_{3}$ & 5,0 & 5,0 & 3,75 & 3,75 & 1,25 & 1,25 & - & - & - & - & - & - \\
\hline $\mathrm{NH}_{4} \mathrm{Cl}$ & - & - & 0,625 & 0,625 & 1,25 & 1,25 & 2,5 & 2,5 & 2,5 & 2,5 & 2,5 & 2,5 \\
\hline $\mathrm{KCl}$ & - & - & 0,625 & 0,625 & 1,25 & 1,25 & 2,5 & 2,5 & 2,5 & 2,5 & 2,5 & 2,5 \\
\hline $\mathrm{CaCl}_{2}$ & - & - & - & - & - & - & - & - & 1,25 & 1,25 & 2,5 & 2,5 \\
\hline Fe-EDTA* & 1 & 1 & 1 & 1 & 1 & 1 & 1 & 1 & 1 & 1 & 1 & 1 \\
\hline Micro-B1** & 1 & - & 1 & - & 1 & - & 1 & - & 1 & - & 1 & - \\
\hline Micro-B2*** & - & 1 & - & 1 & - & 1 & - & 1 & - & 1 & - & 1 \\
\hline
\end{tabular}

* Solução Fe-EDTA = Dissolver 26,1 g de EDTA dissódico em $286 \mathrm{~mL}$ de NaOH mol L $\mathrm{L}^{-1}$; misturar com $24,0 \mathrm{~g}$ de $\mathrm{FeSO}_{4} .7 \mathrm{H}_{2} \mathrm{O}$. Arejar por uma noite, completar a 1 litro e filtrar. Guardar em frasco escuro.

** A solução Micro-B1 tem a seguinte composição $\left(\mathrm{g} \mathrm{L}^{-1}\right) \mathrm{H}_{3} \mathrm{BO}_{3} 0,572, \mathrm{MnCl}_{2} .4 \mathrm{H}_{2} \mathrm{O}, 1,81, \mathrm{ZnCl}_{2}, 0,10$, $\mathrm{CuCl}_{2}, 0,04, \mathrm{H}_{2} \mathrm{MoO}_{4} \cdot \mathrm{H}_{2} \mathrm{O}, 0,02$

*** A solução Micro-B2 tem a seguinte composição $\left(\mathrm{g} \mathrm{L}^{-1}\right) \mathrm{H}_{3} \mathrm{BO}_{3} 2,86, \mathrm{MnCl}_{2} .4 \mathrm{H}_{2} \mathrm{O}, 1,81, \mathrm{ZnCl}_{2}, 0,10$, $\mathrm{CuCl}_{2}, 0,04, \mathrm{H}_{2} \mathrm{MoO}_{4} \cdot \mathrm{H}_{2} \mathrm{O}, 0,02$

\subsection{Amostragens e determinações}

As avaliações foram realizadas aos 55 dias (período que corresponde ao início da floração) e que segundo Sfredo et al. (1983) é uma boa fase para se avaliar o estado nutricional do girassol.

Com a utilização de uma régua, mediu-se a altura das plantas e com o auxílio de um paquímetro, avaliou-se o diâmetro dos caules na altura média das plantas. Para cada vaso, avaliou-se a média das duas plantas para obter-se somente um valor por vaso.

A colheita do experimento foi realizada no dia 01 de junho, dividindo-se a parte aérea das plantas em quatro partes: 
a) folhas do terço superior (FS);

b) terço superior do caule (CS);

c) folhas inferiores (FI);

d) caules inferiores $(\mathrm{CI})$,

sendo que as duas plantas de cada unidade experimental compuseram uma única amostra.

Todo o material colhido foi colocado em estufa com circulação forçada de ar a $65-70^{\circ} \mathrm{C}$ até atingir massa constante, com posterior pesagem. Após a pesagem as partes amostradas foram moídas, acondicionadas em sacos plásticos e encaminhadas para o laboratório do Departamento de Solos e Nutrição de Plantas para a determinação dos macro e micronutrientes.

A obtenção do extrato para a determinação do $\mathrm{N}$ foi realizada através da digestão sulfúrica e a digestão nitro-perclórica foi utilizada para a obtenção dos extratos para as determinações de P, K, Ca, Mg, Cu, Fe, Mn e Zn. Para o boro a amostra foi incinerada em mufla a $550^{\circ} \mathrm{C}$ (Sarruge \& Haag, 1974 e Bataglia et al., 1983).

A determinação do $\mathrm{N}$ foi efetuada pelo método Micro Kjeldhal. O fósforo foi determinado por colorimetria de vanadato molibdato; o $\mathrm{K}$ por fotometria de chama; o $\mathrm{Ca}, \mathrm{Mg}, \mathrm{Cu}, \mathrm{Fe}, \mathrm{Mn}$ e $\mathrm{Zn}$ por espectometria de absorção atômica; o S por turbidimetria e o B por colorimetria de azometina $\mathrm{H}$.

O acúmulo de nutrientes foi calculado em função do peso do material seco e da concentração em cada parte da planta estudada.

\subsection{Análises estatísticas}

Os resultados da massa do material seco da parte aérea das plantas e o acúmulo de nutrientes nos tecidos, foram submetidos à análise de variância.

Quando houve interação significativa entre doses de cálcio e peso do material seco, acúmulo de boro ou acúmulo de cálcio, prosseguiu-se a análise estatística com cálculo das regressões polinomiais, com $\mathrm{P}<0,01$. 
As análises estatísticas foram realizadas utilizando-se o programa estatístico SAS-System for Windows release 6.11 (SAS, Institute Incorporation, 1996).

Para a análise das alturas e dos diâmetros, utilizou-se o programa estatístico ESTAT. 


\section{RESULTADOS E DISCUSSÃO}

\subsection{Produção de material vegetal seco}

Os resultados obtidos para produção de material vegetal seco das partes das plantas, em função dos 12 tratamentos, são apresentados nas Tabelas 2 e 3 . Verifica-se que a produção de material vegetal seco da parte aérea das plantas de girassol foi crescente com o aumento das doses de cálcio. Hill \& Morril (1975) observaram que doses elevadas de cálcio na ausência da aplicação de boro resultaram em acréscimos na produção de amendoim.

Observando-se a produção de material vegetal seco total da parte aérea dos dois cultivares estudados, verificou-se que no tratamento com maior dose de cálcio (300 $\mathrm{mg} \mathrm{L}^{-1}$ ) e com dose de $0,5 \mathrm{mg} \mathrm{L}^{-1}$ de $B$ foram obtidas maiores produções. Resultados semelhantes foram encontrados em plantas de girassol por Baumgartner et al. (1986). Isso indica que para os cultivares estudados há necessidade de estudo com doses mais elevadas de cálcio para estabelecer-se o nível de máxima produção de material seco.

A análise de variância para a produção de material vegetal seco das partes das plantas revelou significância $(\mathrm{P}<0,01)$ para a interação entre as doses de cálcio e de boro.

$\mathrm{Na}$ decomposição da interação entre doses de cálcio e boro a resposta da produção de material vegetal seco de cada cultivar foi representada através das equações apresentadas nas Figuras 2 a 6. 
Tabela 2 - Produção de material vegetal seco nas partes das plantas na variedade IACUruguai em função das doses de cálcio e boro na solução nutritiva. Média de quatro repetições.

\begin{tabular}{|c|c|c|c|c|c|c|c|c|c|c|}
\hline \multicolumn{11}{|c|}{ Quantidade de material seco $(\mathrm{g})$} \\
\hline \multirow{3}{*}{$\begin{array}{c}\mathrm{Ca} \\
\left(\mathrm{mg} \mathrm{L}^{-1}\right)\end{array}$} & \multicolumn{10}{|c|}{$\mathrm{B}\left(\mathrm{mg} \mathrm{L}^{-1}\right)$} \\
\hline & \multicolumn{2}{|c|}{ FS } & \multicolumn{2}{|c|}{ FI } & \multicolumn{2}{|c|}{$\mathrm{CS}$} & \multicolumn{2}{|c|}{$\mathrm{CI}$} & \multicolumn{2}{|c|}{ Total } \\
\hline & 0,1 & 0,5 & 0,1 & 0,5 & 0,1 & 0,5 & 0,1 & 0,5 & 0,1 & 0,5 \\
\hline 0 & 9,61 & 9,11 & 1,94 & 3,69 & 2,80 & 2,50 & 7,64 & 11,14 & 21,99 & 26,44 \\
\hline 50 & 12,08 & 8,96 & 2,21 & 4,48 & 3,69 & 3,37 & 9,92 & 16,53 & 27,90 & 33,34 \\
\hline 100 & 10,91 & 8,54 & 1,72 & 4,09 & 3,41 & 3,63 & 10,34 & 16,48 & 26,38 & 32,74 \\
\hline 200 & 12,65 & 10,41 & 3,32 & 6,06 & 3,51 & 3,71 & 10,50 & 20,34 & 29,98 & 40,52 \\
\hline 250 & 11,80 & 9,42 & 2,97 & 5,71 & 3,31 & 3,40 & 9,38 & 17,64 & 27,46 & 36,17 \\
\hline 300 & 11,12 & 11,65 & 3,70 & 6,50 & 2,84 & 3,59 & 11,27 & 19,23 & 28,93 & 40,97 \\
\hline
\end{tabular}

Tabela 3 - Produção de material vegetal seco nas partes das plantas no híbrido Rumbossol-91 em função das doses de cálcio e boro na solução nutritiva. Média de quatro repetições.

\begin{tabular}{cccccccccccc}
\hline \multicolumn{10}{c}{ Ca } & \multicolumn{10}{c}{ Quantidade de material seco $(\mathrm{g})$} \\
\cline { 2 - 13 }$\left(\mathrm{mg} \mathrm{L}^{-1}\right)$ & \multicolumn{10}{c}{ FS } & \multicolumn{10}{c}{ FI $\left(\mathrm{mg} \mathrm{L}^{-1}\right)$} \\
& 0,1 & 0,5 & 0,1 & 0,5 & 0,1 & 0,5 & 0,1 & 0,5 & 0,1 & 0,5 \\
\hline 0 & 9,69 & 9,99 & 2,34 & 3,45 & 1,96 & 2,64 & 4,98 & 10,98 & 18,97 & 27,06 \\
50 & 11,10 & 8,71 & 2,76 & 4,30 & 2,91 & 2,49 & 9,76 & 13,40 & 26,53 & 28,90 \\
100 & 12,56 & 10,50 & 3,00 & 3,96 & 2,50 & 2,79 & 9,70 & 14,83 & 27,76 & 32,08 \\
200 & 13,76 & 11,91 & 3,15 & 5,55 & 2,85 & 2,99 & 9,43 & 15,11 & 29,19 & 35,56 \\
250 & 13,46 & 10,76 & 3,61 & 5,19 & 2,52 & 2,83 & 8,70 & 14,87 & 28,29 & 33,95 \\
300 & 15,12 & 11,63 & 3,80 & 6,52 & 3,13 & 3,21 & 9,35 & 17,81 & 31,40 & 39,17 \\
\hline
\end{tabular}

\section{Folhas superiores}

Considerando-se a produção de material vegetal seco das folhas superiores (Figura 2), verificaram-se diferenças entre as duas doses de boro, destacando-se que na menor dose $\left(0,1 \mathrm{mg} \mathrm{L}^{-1}\right.$ de $\left.\mathrm{B}\right)$ houve maior produção de material seco das folhas superiores, variando de 9,61 a 12,65 g para a variedade IAC-Uruguai e de 9,69 a 15,12 g para o híbrido Rumbossol-91 (Tabelas 2 e 3). 
Para ambos os cultivares, quando submetidos à dose $0,1 \mathrm{mg} \mathrm{L}^{-1}$ de $\mathrm{B}$, os resultados responderam segundo um modelo quadrático. Verifica-se na Figura 2, que para a variedade IAC-Uruguai, submetida a $0,1 \mathrm{mg} \mathrm{L}^{-1}$ de $\mathrm{B}$, a maior produção de material seco das folhas superiores ocorreu quando a dose de cálcio foi de $200 \mathrm{mg} \mathrm{L}^{-1}$, decrescendo nas doses mais elevadas. Apesar desse comportamento, para a dose de boro $0,5 \mathrm{mg} \mathrm{L}^{-1}$, percebe-se uma tendência crescente de produção de material vegetal seco das folhas superiores de acordo com a elevação das doses de cálcio no substrato. Isso sugere que a produção de material vegetal seco das folhas superiores é influenciada pelas doses de cálcio, quando supridas adequadamente com boro.

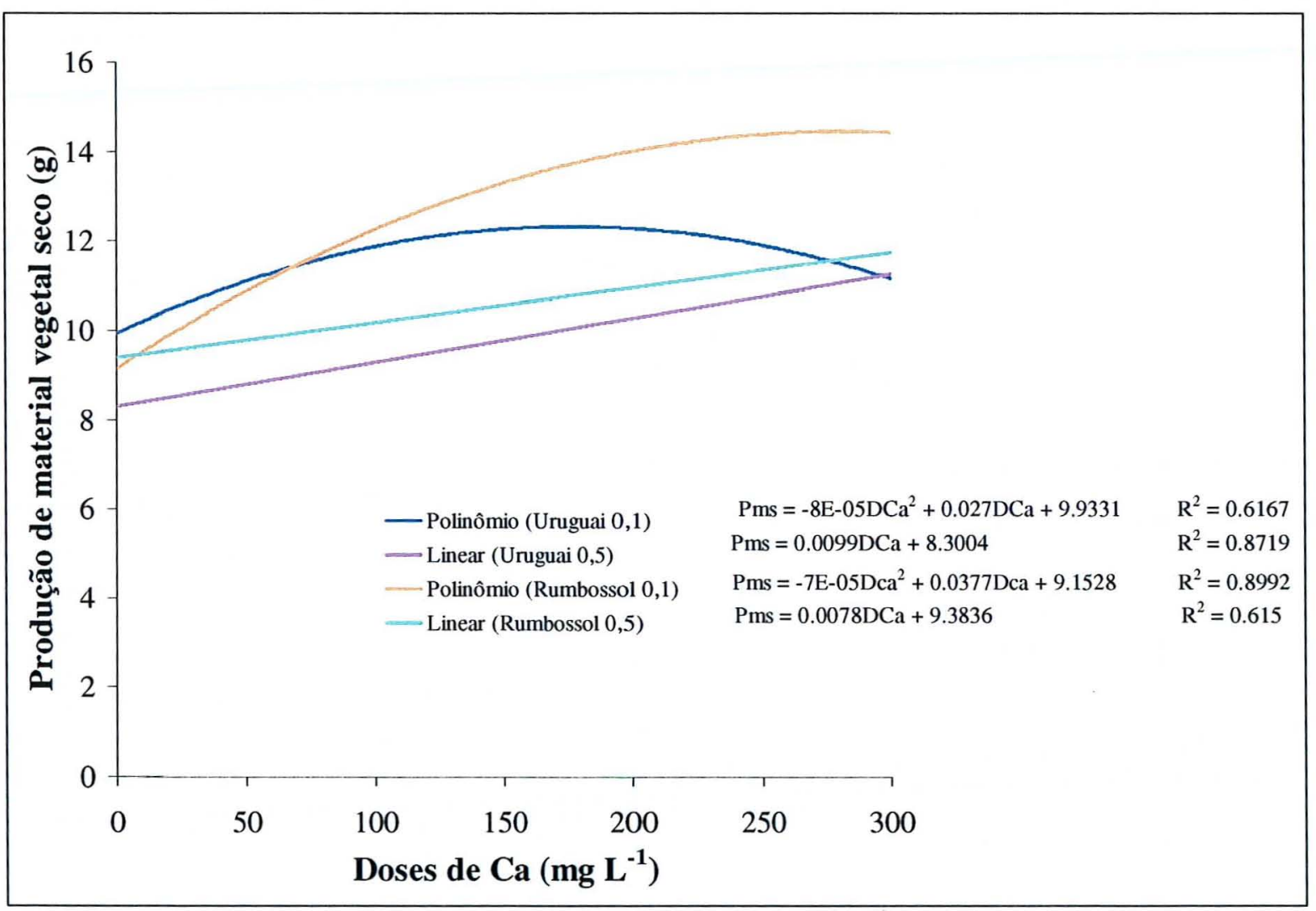

Figura 2 - Produção de material vegetal seco das folhas superiores de dois cultivares de girassol (IAC-Uruguai e Rumbossol-91) em função das doses de cálcio e boro na solução nutritiva. Média de quatro repetições. 


\section{Folhas inferiores}

Na Figura 3, observam-se as produções de material vegetal seco das folhas inferiores dos dois cultivares. Ambos apresentaram respostas lineares, nas quais não se verificaram ponto de produção máxima.

Nota-se que, a variedade IAC-Uruguai submetida ao tratamento com a dose de $0,5 \mathrm{mg} \mathrm{L}^{-1}$ de $\mathrm{B}$ foi a que apresentou maior produção de material vegetal seco das folhas inferiores. Nos dois cultivares estudados, menores produções foram encontradas no tratamento com dose de $0,1 \mathrm{mg} \mathrm{L}^{-1}$ de $\mathrm{B}$.

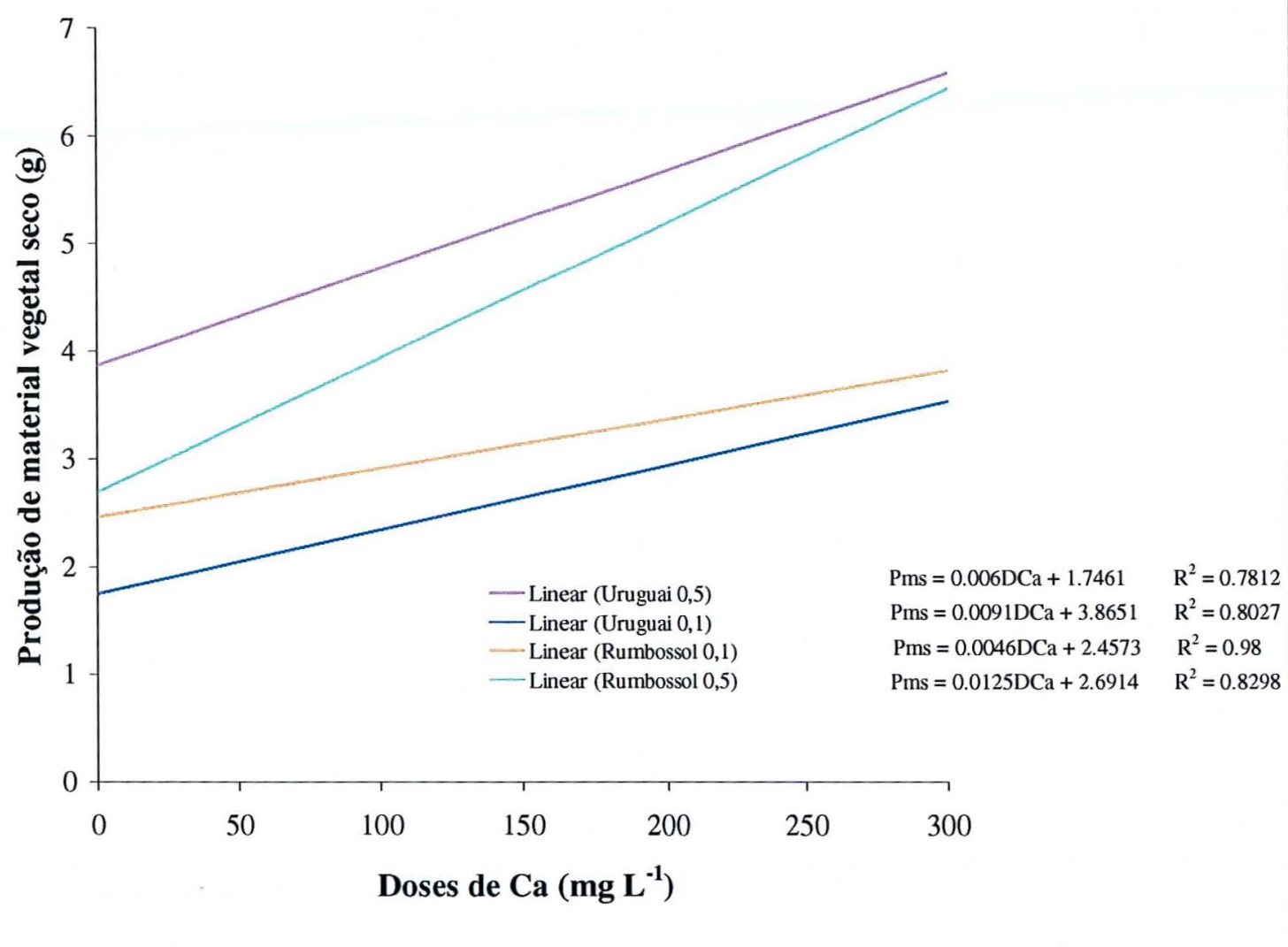

Figura 3 - Produção de material vegetal seco das folhas inferiores de dois cultivares de girassol (IAC-Uruguai e Rumbossol-91) em função das doses de cálcio e boro na solução nutritiva. Média de quatro repetições. 


\section{Caules superiores}

A produção de material vegetal seco do terço superior dos caules para a variedade IAC-Uruguai, nas doses 0,1 e $0,5 \mathrm{mg} \mathrm{L}^{-1}$ de $\mathrm{B}$, ajustaram-se a equações quadráticas, com pontos de produção máxima de 3,69 e 3,71 g, respectivamente (Figura 4). Para o híbrido Rumbossol-91 os ajustes foram de acordo com equações lineares, não atingindo ponto de produção máxima. Verificou-se na variedade IAC-Uruguai diminuição na produção de material seco dos caules superiores após a dose $200 \mathrm{mg} \mathrm{L}^{-1}$ de cálcio, independentemente da dose de boro fornecida. No híbrido Rumbossol-91, quanto maior foi a dose de cálcio, maior foi a produção de material seco dos caules superiores. Isso indica que os dois cultivares apresentaram diferenças quanto ao aproveitamento dos nutrientes estudados.

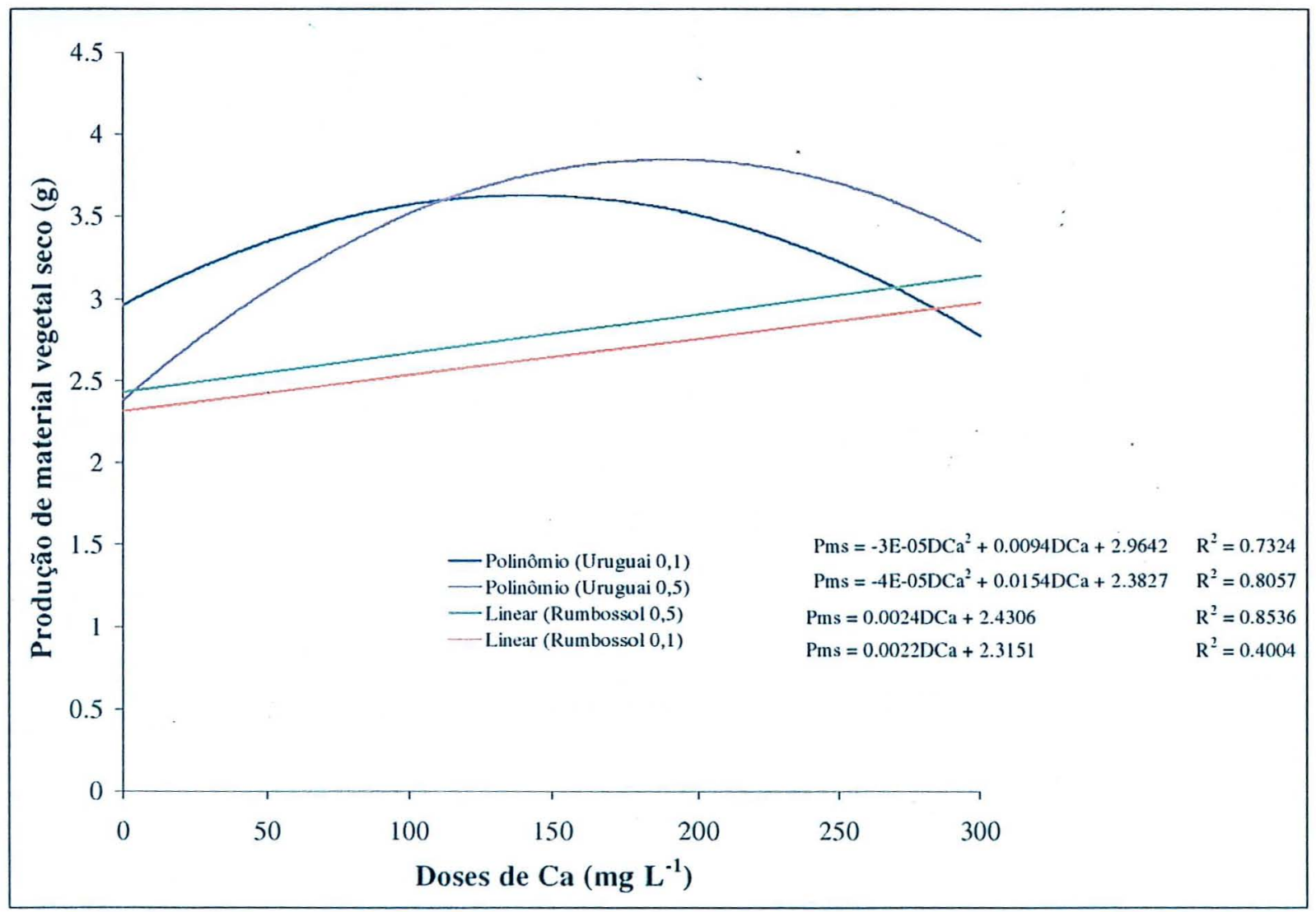

Figura 4 - Produção de material vegetal seco de caules superiores de dois cultivares de girassol (IAC-Uruguai e Rumbossol-91) em função das doses de cálcio e boro na solução nutritiva. Média de quatro repetições. 


\section{Caules inferiores}

A Figura 5 apresenta a produção de material vegetal seco dos caules inferiores dos dois cultivares em função das doses de cálcio e boro. Verifica-se que não houve interação para a variedade IAC-Uruguai, quando se aplicou a dose $0,1 \mathrm{mg} \mathrm{L}^{-1}$ de B. As demais respostas ajustaram-se a modelos quadráticos, sendo que a variedade IACUruguai foi a que produziu maior peso de material seco com a dose de $0,5 \mathrm{mg} \mathrm{L}^{-1}$ de $\mathrm{B}$. Para o híbrido Rumbossol-91, a maior produção também ocorreu no tratamento com maior dose de boro.

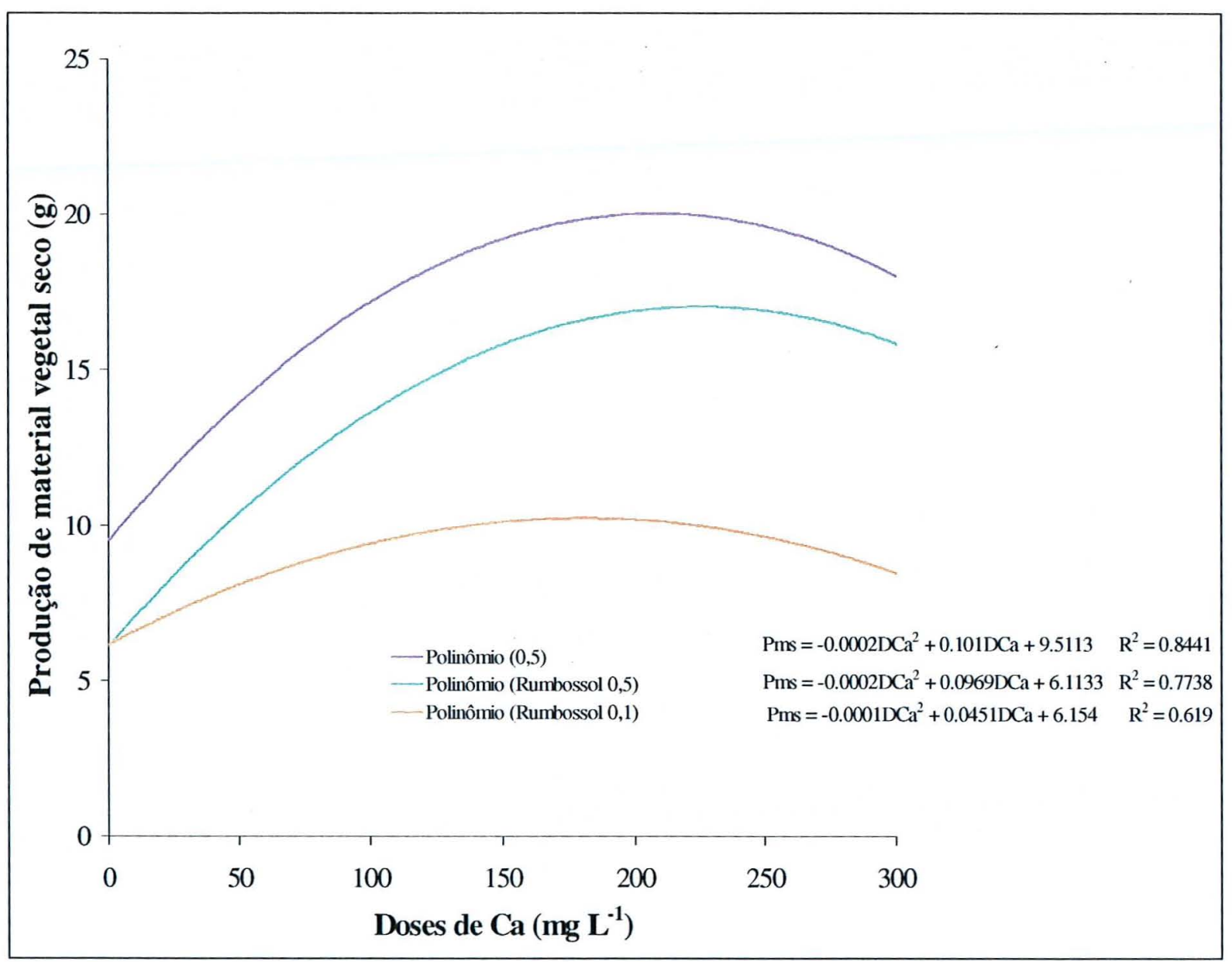

Figura 5 - Produção de material vegetal seco de caules inferiores de dois cultivares de girassol (IAC-Uruguai e Rumbossol-91) em função das doses de cálcio e boro na solução nutritiva. Média de quatro repetições. 
Avaliando os tratamentos estudados sugere-se um ótimo de $0,5 \mathrm{mg} \mathrm{L}^{-1}$ de $\mathrm{B}$ e $300 \mathrm{mg} \mathrm{L}^{-1}$ de Ca para a melhor produção de material vegetal seco, correspondendo a uma relação B:Ca de 1:600. Relações inferiores (1:80) foram encontradas por Oyewole \& Aduayi (1992) em estudos com tomateiro.

A Figura 6 apresenta a produção de material seco da parte aérea dos dois cultivares em função das doses de cálcio e boro na solução nutritiva. As produções responderam segundo modelo quadrático para a variedade IAC-Uruguai e para o híbrido Rumbossol-91. O ponto de produção máxima foi observado na dose de $0,5 \mathrm{mg} \mathrm{L}^{-1}$ de boro para os dois cultivares, mostrando a importância do boro na produção de material seco das plantas.

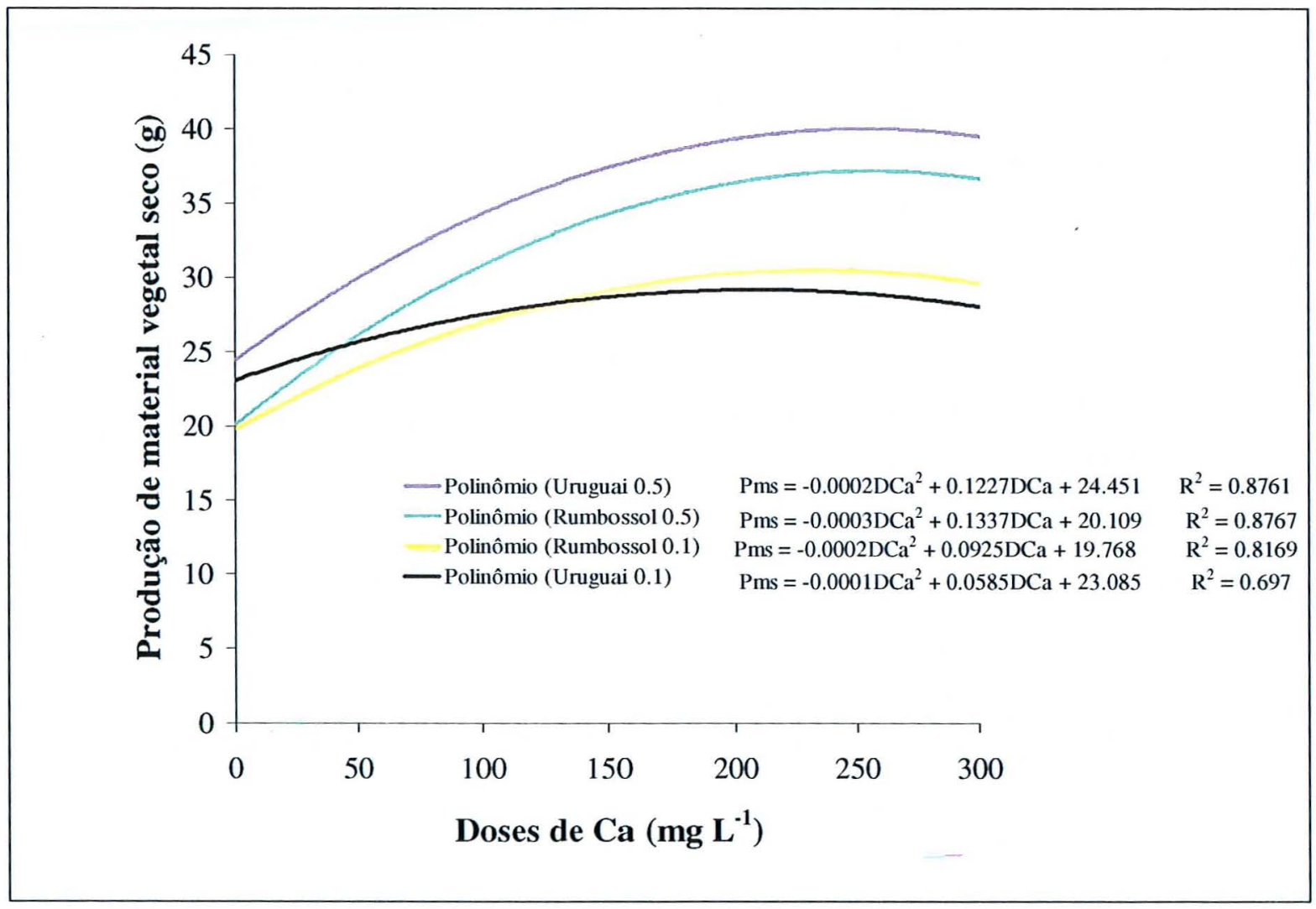

Figura 6 - Produção de material vegetal seco da parte aérea de dois cultivares de girassol (IAC-Uruguai e Rumbossol-91) em função das doses de cálcio e boro na solução nutritiva. Média de quatro repetições. 


\subsubsection{Altura e diâmetro dos caules das plantas}

Analisando-se as alturas e os diâmetros dos caules das plantas, não se verificou interação entre doses de cálcio e boro para essas características. Assim sendo, estudou-se o efeito dos nutrientes isoladamente.

De acordo com as Tabelas 4, 5, 6 e 7, para a variedade IAC-Uruguai e para o híbrido Rumbossol-91, verificou-se diferenças significativas entre as doses de boro estudadas, sendo que nos tratamentos com $0,5 \mathrm{mg} \mathrm{L}^{-1}$ de $\mathrm{B}$ foram encontradas maiores alturas e diâmetros dos caules das plantas. Oyewole \& Aduayi (1992) encontraram que na presença de $2 \mathrm{mg} \mathrm{L}^{-1}$ de $\mathrm{B}$, sem adição de cálcio, resultou em incremento no número de folhas e no diâmetro do caule de plantas de tomateiro.

Tabela 4 - Análise das alturas dos caules das plantas $(\mathrm{cm})$ da variedade IAC-Uruguai submetida a doses de cálcio e boro na solução nutritiva. Média de quatro repetições.

\begin{tabular}{c|cccccc|c}
\hline $\mathrm{B}$ & \multicolumn{7}{c|}{$\mathrm{Ca}\left(\mathrm{mg} \mathrm{L}^{-1}\right)$} \\
$\left(\mathrm{mg} \mathrm{L}^{-1}\right)$ & 0 & 50 & 100 & 200 & 250 & 300 & Médias \\
\cline { 2 - 8 } 0,1 & 49,43 & 54,37 & 61,00 & 47,87 & 48,31 & 64,50 & $54,250 \mathrm{~b}$ \\
0,5 & 65,12 & 87,50 & 89,06 & 88,37 & 85,87 & 84,06 & $82,254 \mathrm{a}$ \\
\hline Médias & 54,044 & 70,937 & 75,031 & 68,125 & 67,094 & 74,281 & \\
\hline c.v $=18,3883 \%$ \\
médias seguidas de mesma letra não diferem entre si pelo teste de Tukey em nivel de 5\%.
\end{tabular}

Tabela 5 - Análise das alturas dos caules das plantas (cm) do híbrido Rumbossol-91 submetido a doses de cálcio e boro na solução nutritiva. Média de quatro repetições.

\begin{tabular}{c|cccccc|c}
\hline & \multicolumn{7}{|c|}{$\mathrm{Ca}\left(\mathrm{mg} \mathrm{L}^{-1}\right)$} \\
$\left(\mathrm{mg} \mathrm{L}^{-1}\right)$ & 0 & 50 & 100 & 200 & 250 & 300 & Médias \\
\cline { 2 - 8 } 0,1 & 40,00 & 44,50 & 43,37 & 46,62 & 47,00 & 48,75 & $45,042 \mathrm{~b}$ \\
0,5 & 51,75 & 57,12 & 63,25 & 61,62 & 61,00 & 65,50 & $59,112 \mathrm{a}$ \\
\hline Médias & 43,087 & 50,812 & 53,312 & 54,125 & 54,000 & 57,125 & \\
\hline c.v $=11,7394 \%$ \\
médias seguidas de mesma letra não diferem entre si pelo teste de Tukey em nível de $5 \%$.
\end{tabular}


Tabela 6 - Análise dos diâmetros dos caules $(\mathrm{cm})$ das plantas da variedade IAC-Uruguai submetida a doses de cálcio e boro na solução nutritiva. Média de quatro repetições.

\begin{tabular}{c|cccccc|c}
\hline \multirow{2}{*}{$\begin{array}{c}\mathrm{B} \\
(\mathrm{mg} \mathrm{L}\end{array}$} & \multicolumn{6}{|c|}{$\mathrm{Ca}\left(\mathrm{mg} \mathrm{L}^{-1}\right)$} & \\
\cline { 2 - 8 } 0,1 & 0 & 50 & 100 & 200 & 250 & 300 & Médias \\
\cline { 2 - 8 } 0,5 & 0,93 & 1,00 & 1,00 & 1,01 & 1,07 & 1,04 & $1,049 \mathrm{~b}$ \\
\hline Médias & 0,097 & 1,05 & 1,06 & 1,08 & 1,10 & 1,18 & $1,081 \mathrm{a}$ \\
\hline
\end{tabular}

c.v $=6,7541 \%$

médias seguidas de mesma letra não diferem entre si pelo teste de Tukey em nível de $5 \%$.

Tabela 7 - Análise dos diâmetros dos caules (cm) das plantas do híbrido Rumbossol-91 submetido a doses de cálcio e boro na solução nutritiva. Média de quatro repetições.

\begin{tabular}{c|cccccc|c}
\hline \multirow{2}{*}{$\begin{array}{c}\mathrm{B} \\
\left(\mathrm{mg} \mathrm{L}^{-1}\right)\end{array}$} & 0 & 50 & 100 & 200 & 250 & 300 & Médias \\
\cline { 2 - 8 } 0,1 & 0,94 & 1,03 & 1,05 & 1,08 & 1,10 & 1,08 & $1,013 \mathrm{~b}$ \\
0,5 & 0,99 & 1,07 & 1,03 & 1,12 & 1,11 & 1,14 & $1,078 \mathrm{a}$ \\
\hline Médias & 0,968 & 0,105 & 0,104 & 0,110 & 0,110 & 0,111 & \\
\hline c.v $=4,4887 \%$
\end{tabular}

médias seguidas de mesma letra não diferem entre si pelo teste de Tukey em nível de $5 \%$.

A influência das doses de cálcio nas alturas e nos diâmetros dos caules das plantas foi verificada através do estudo de regressões obtendo-se as Figuras 7 e 8.

Todas as equações responderam segundo modelo quadrático, com aumentos significativos nas alturas e nos diâmetros de acordo com as doses de cálcio fornecidas na solução nutritiva.

A maior altura foi observada na dose de $200 \mathrm{mg} \mathrm{L}^{-1}$ de Ca para a variedade IACUruguai e para o híbrido Rumbossol-91 não se verificou ponto de inflexão na curva.

Os diâmetros dos caules aumentaram de acordo com as doses de cálcio na solução nutritiva (Figura 8). No híbrido Rumbossol-91 maior diâmetro do caule foi observado na dose de $300 \mathrm{mg} \mathrm{L}^{-1}$ de Ca. 


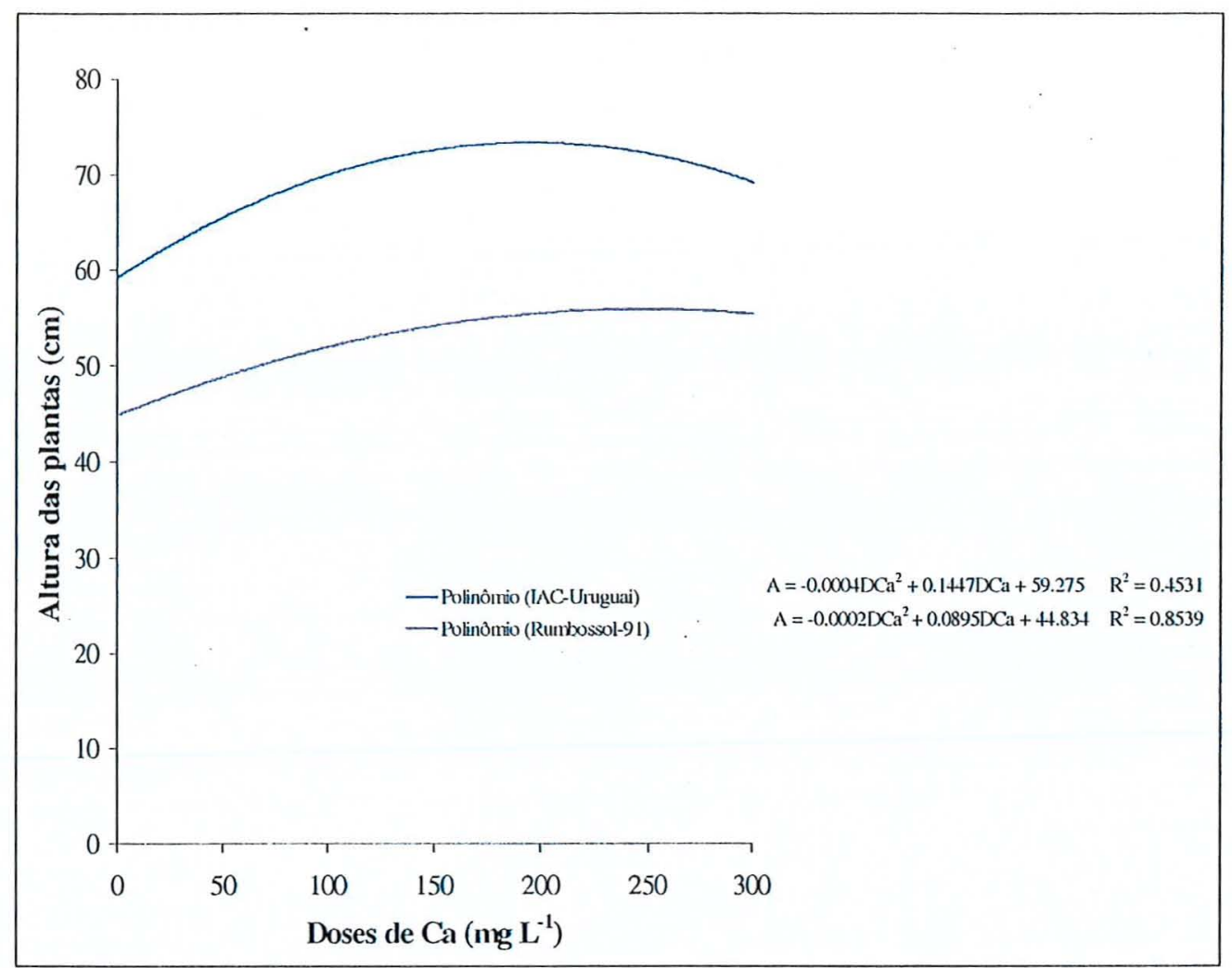

Figura 7 - Altura dos caules das plantas de dois cultivares de girassol (IAC-Uruguai e Rumbossol-91) em função das doses de cálcio na solução nutritiva. Média de quatro repetições. 


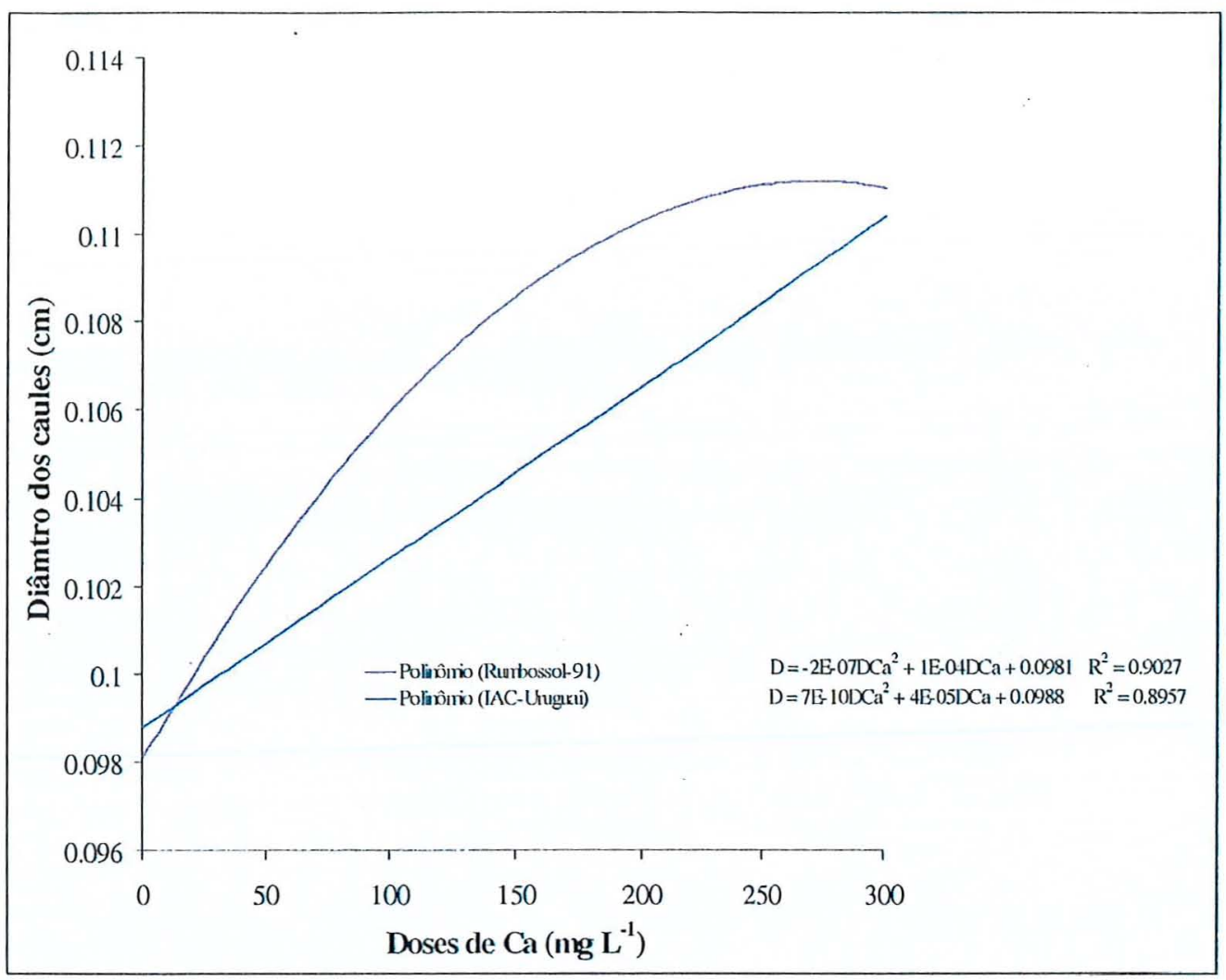

Figura 8 - Diâmetro dos caules das plantas de dois cultivares de girassol (IAC-Uruguai e Rumbossol-91) em função das doses de cálcio na solução nutritiva. Média de quatro repetições.

\subsection{Sintomas visuais de deficiência}

Diferenças visuais quanto ao desenvolvimento das plantas entre os tratamentos puderam ser observadas a partir da primeira semana após a aplicação dos tratamentos. Concordando com Marschner (1995), os sintomas de deficiência de boro ocorreram em regiões apicais, afetando principalmente os tecidos meristemáticos.

As plantas com doses baixas de cálcio e boro apresentaram os mesmos sintomas. Paralização do crescimento, folhas com manchas necróticas de tecido seco (Figura 9), escurecimento da região apical, com posterior necrose dos tecidos internos (Figura 9 e 10) e encurtamento internodal foram os sintomas mais frequentes. As plantas submetidas aos tratamentos com $0 \mathrm{mg} \mathrm{L}^{-1}$ de cálcio (Tratamentos 1 e 2) foram os que apresentaram 
sintomas mais acentuados de deficiência, ocorrendo até morte da gema apical (Figura 10 e 11).

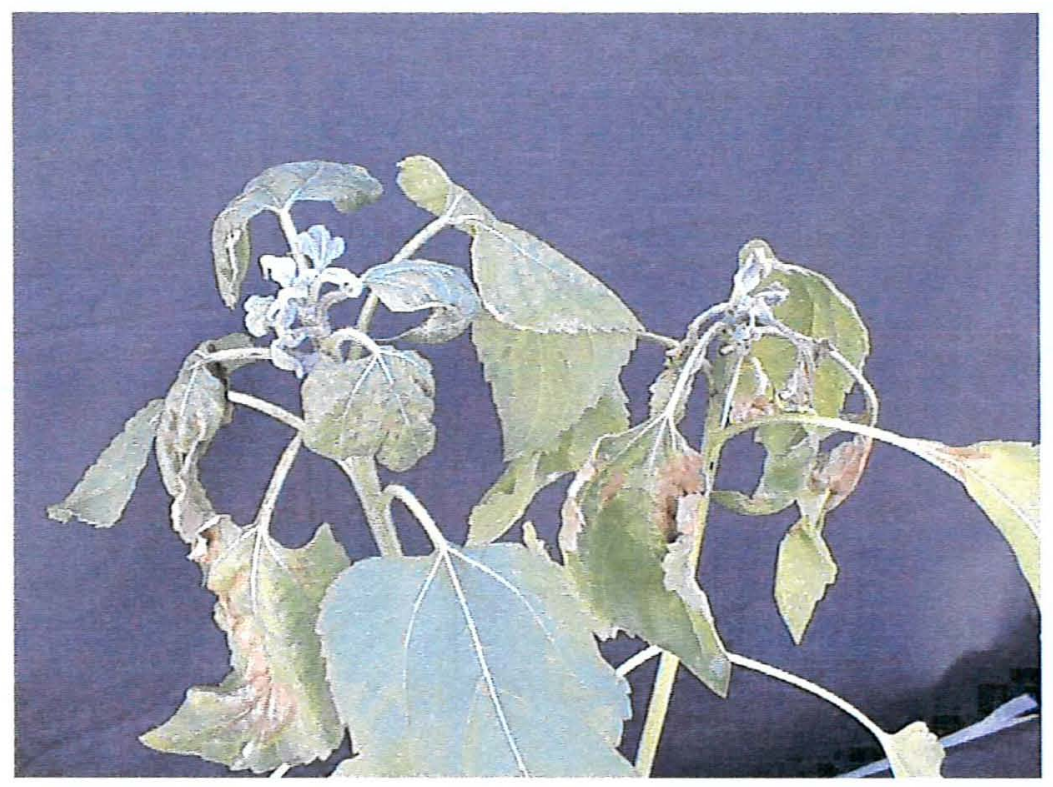

Figura 9 - Sintomas de deficiência de cálcio e de boro na variedade IACUruguai submetida ao tratamento com $50 \mathrm{mg} \mathrm{L}^{-1}$ de Ca e $0,1 \mathrm{mg} \mathrm{L}^{-1}$ de B. 


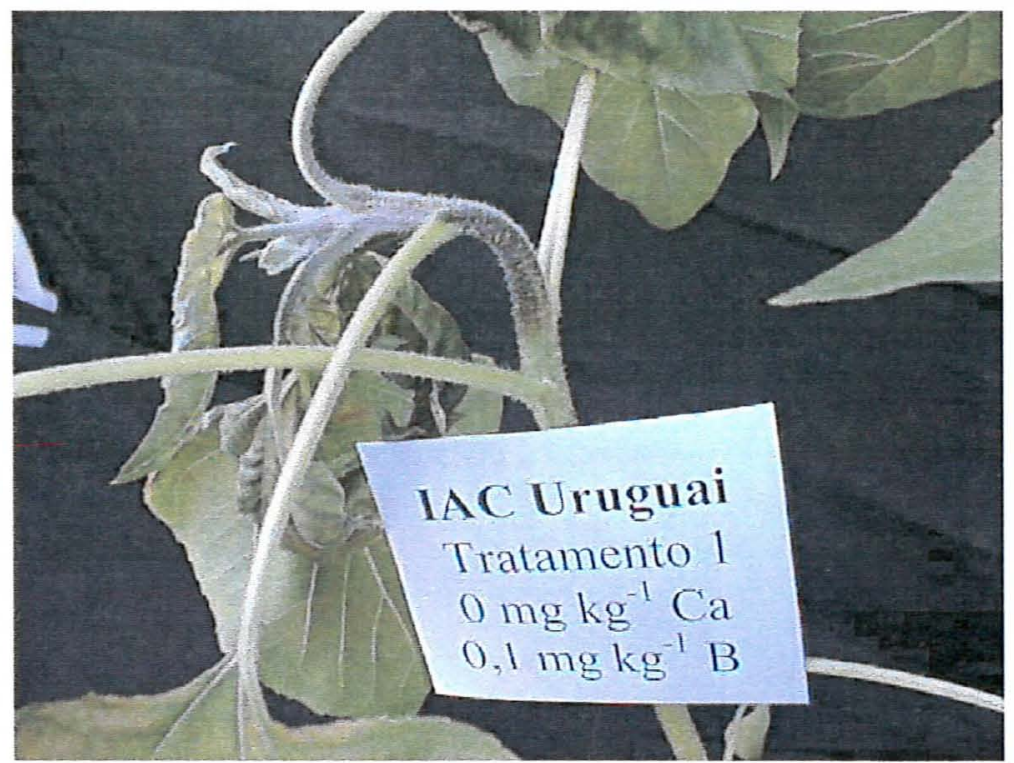

Figura 10 - Sintomas de deficiência de cálcio e de boro na variedade IACUruguai submetida ao tratamento com $0 \mathrm{mg} \mathrm{L}^{-1}$ de Ca e 0,1 $\mathrm{mg} \mathrm{L}^{-1}$ de B.

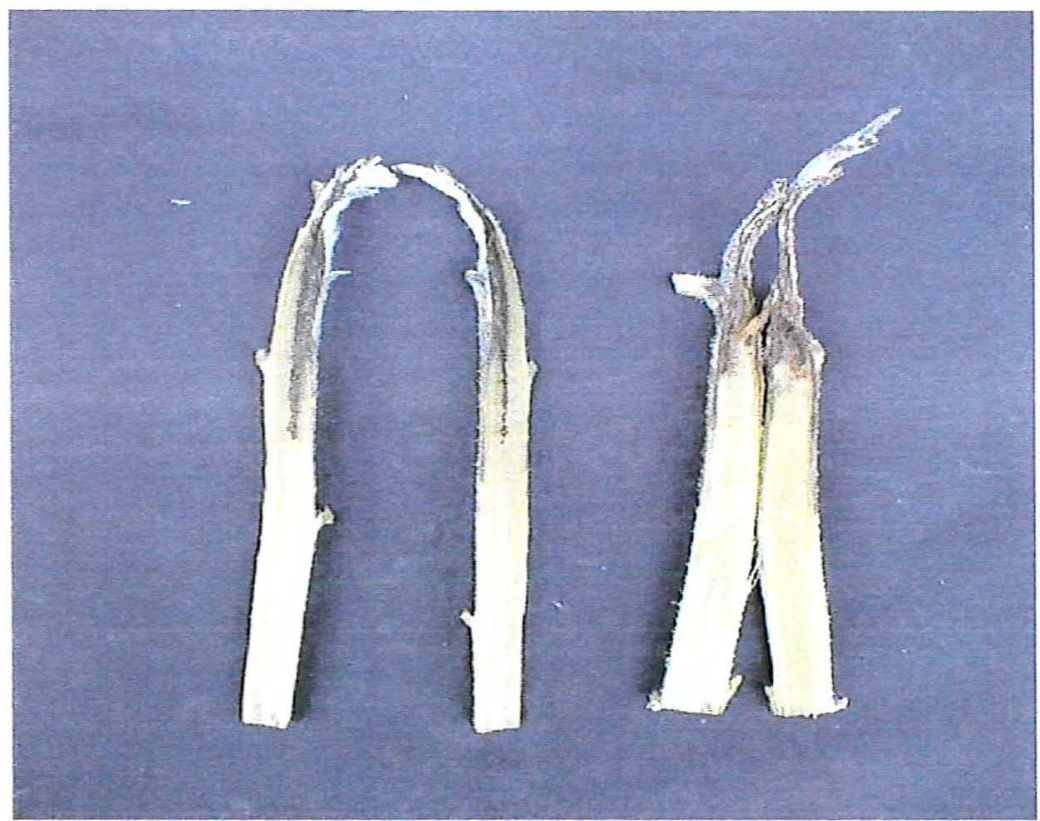

Figura 11 - Sintoma de deficiência de cálcio e de boro num corte longitudinal do terço superior de caules da variedade IAC-Uruguai submetidos ao tratamento com $0 \mathrm{mg} \mathrm{L}^{-1}$ de $\mathrm{Ca}$ e $0,1 \mathrm{mg} \mathrm{L}^{-1}$ de B. 
Independentemente da quantidade de cálcio fornecida nas soluções nutritivas, os tratamentos com $0,1 \mathrm{mg} \mathrm{L}^{-1}$ de B apresentararam sintomas de deficiência de boro. De acordo com Hill \& Morrill (1975), apesar do surgimento dos sintomas, a adição de cálcio resultou em aumento expressivo no crescimento das plantas.

Segundo Gupta (1993), citado por Brown \& Shelp (1997), sintomas de deficiência de boro aparecem quando os tecidos apresentam concentrações entre 20-30 $\mathrm{mg} \mathrm{kg}{ }^{-1}$ de peso do material vegetal seco em dicotiledôneas; entre $10-20 \mathrm{mg} \mathrm{kg}^{-1}$ de peso do material seco em milho e menos que $10 \mathrm{mg} \mathrm{kg}^{-1}$ em trigo.

\subsection{Nutrientes}

Pode-se verificar na Tabela 8 as concentrações de macro e micronutrientes encontradas nas plantas que receberam $200 \mathrm{mg} \mathrm{L}^{-1}$ de $\mathrm{Ca}$ e $0,5 \mathrm{mg} \mathrm{L}^{-1}$ de $\mathrm{B}$ (tratamento 8) que é o recomendado por Sarruge (1975).

Na Figura 12 é possível observar a diferença entre o tratamento com as doses recomendadas por Sarruge (1975) e o tratamento com dose inferior de cálcio.

Tabela 8 - Concentrações (C) e acúmulos (A) de macro e micronutrientes na matéria seca da parte aérea. Média de quatro repetições.

\begin{tabular}{|c|c|c|c|c|}
\hline & \multicolumn{4}{|c|}{ Cultivares } \\
\hline & \multicolumn{2}{|c|}{ IAC-Uruguai } & \multicolumn{2}{|c|}{ Rumbossol-91 } \\
\hline & $\mathrm{C}$ & $\mathrm{A}$ & $\mathrm{C}$ & A \\
\hline Macronutrientes & $\left(\mathrm{g} \mathrm{kg}^{-1}\right)$ & $(\mathrm{mg})$ & $\left(\mathrm{g} \mathrm{kg}^{-1}\right)$ & $(\mathrm{mg})$ \\
\hline $\mathrm{N}$ & 16,28 & 570,13 & 13,97 & 483,12 \\
\hline $\mathrm{P}$ & 2,85 & 101,44 & 2,71 & 91,49 \\
\hline K & 19,51 & 629,54 & 16,35 & 493,13 \\
\hline $\mathrm{Ca}$ & 10,46 & 334,56 & 11,19 & 332,64 \\
\hline $\mathrm{Mg}$ & 6,38 & 210,95 & 5,68 & 173,33 \\
\hline $\mathrm{S}$ & 2,85 & 95,04 & 2,49 & 82,22 \\
\hline Micronutrientes & $\left(\mathrm{mg} \mathrm{kg}^{-1}\right)$ & $(\mu \mathrm{g})$ & $\left(\mathrm{mg} \mathrm{kg}^{-1}\right)$ & $(\mu \mathrm{g})$ \\
\hline $\mathrm{B}$ & 57,98 & 1685,67 & 59,25 & 1706,47 \\
\hline $\mathrm{Cu}$ & 3,53 & 157,61 & 4,44 & 149,76 \\
\hline $\mathrm{Fe}$ & 133,91 & 4631,43 & 114,54 & 4018,60 \\
\hline $\mathrm{Mn}$ & 60,80 & 2042,35 & 54,89 & 1772,70 \\
\hline $\mathrm{Zn}$ & 12,47 & 429,32 & 9,25 & 341,11 \\
\hline
\end{tabular}




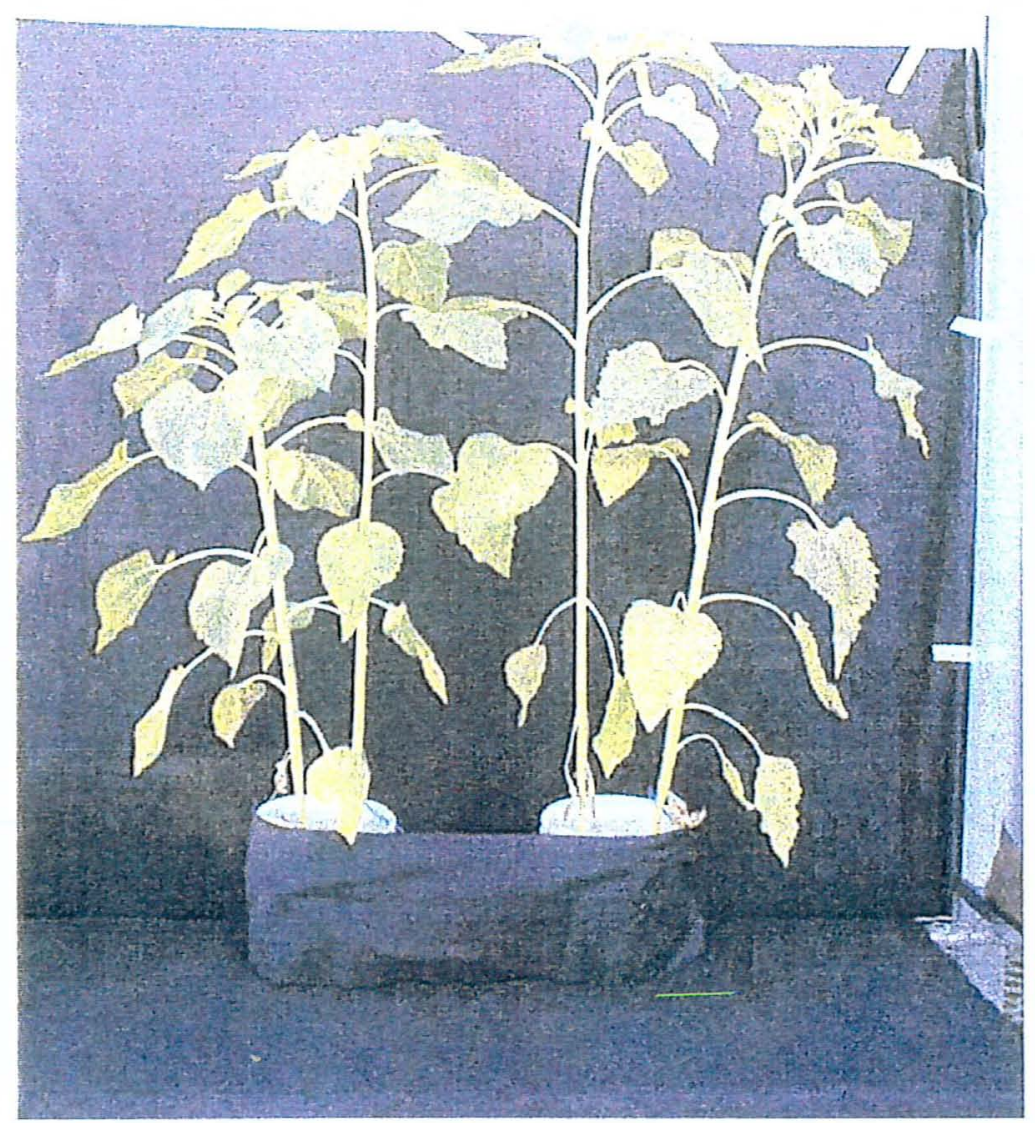

Figura 12 - Comparação visual entre os tratamentos com $100 \mathrm{mg} \mathrm{L}^{-1}$ de Ca e $0,5 \mathrm{mg} \mathrm{L}^{-1}$ de $\mathrm{B}$ (vaso da esquerda) e com $200 \mathrm{mg} \mathrm{L}^{-1}$ de Ca e $0,5 \mathrm{mg} \mathrm{L}^{-1}$ de $\mathrm{B}$ (vaso da direita) na variedade IAC-Uruguai.

Os acúmulos totais de micronutrientes absorvidos pelas plantas de girassol obedeceram à seguinte ordem: $\mathrm{Fe}>\mathrm{Mn}>\mathrm{B}>\mathrm{Zn}>\mathrm{Cu}$, concordando com dados de Sfredo et al. (1983)a.

Em relação aos macronutrientes, as quantidades totais absorvidas pela plantas obedeceram à seguinte ordem: $\mathrm{K}>\mathrm{N}>\mathrm{Ca}>\mathrm{Mg}>\mathrm{P}>\mathrm{S}$. Esses dados podem ser observados na Tabela 8 e estão de acordo com Sfredo et al. (1983)b. 


\subsubsection{Concentração e acúmulo de boro nas partes das plantas}

Nas Tabelas de 9 a 12, verificam-se diferenças em relação ao acúmulo dos nutrientes nas partes das plantas. Quanto maior a quantidade de boro fornecida na solução nutritiva, maior foi a concentração desse nutriente nas partes das plantas, concordando com os dados de Oyewole \& Aduayi (1992) e Gupta \& MacLeod (1997).

Yamauchi et al. (1986), estudando a distribuição do cálcio e do boro no tomateiro, encontraram concentrações de boro semelhantes as encontradas no girassol. Em folhas superiores de tomateiro com deficiência de boro a concentração foi de $26 \mathrm{mg}$ $\mathrm{kg}^{-1}$, em doses suficientes de boro a concentração encontrada foi de $57 \mathrm{mg} \mathrm{kg}^{-1}$ (Tabelas 9 a 12).

Nos cultivares de girassol IAC-Uruguai e Rumbossol-91 verificou-se maiores concentrações de boro nas folhas do que em outras partes das plantas (Tabelas 9 a 12). Resultados semelhantes foram encontrados por Kohl \& Oertli (1961) em plantas de lírio.

Segundo Sfredo \& Sarruge (1990) a concentração de boro em folhas de girassol no início da floração foi de 90 e $100 \mathrm{mg} \mathrm{kg}^{-1}$ de boro para o cultivar Contissol e Guayacan, respectivamente. Entretanto, observando-se as Tabelas 10 e 12, verifica-se que a concentração encontrada no tratamento com $200 \mathrm{mg} \mathrm{L}^{-1}$ de Ca e $0,5 \mathrm{mg} \mathrm{L}^{-1}$ de B (tratamento 8 ), foi de 196,78 e $180,95 \mathrm{mg} \mathrm{kg}^{-1}$ de $\mathrm{B}$ nas folhas para a variedade IACUruguai e para o híbrido Rumbossol-91, respectivamente. 
Tabela 9 - Concentração de boro no material vegetal seco (C) e acúmulo de boro (A) nas várias partes da planta da variedade IAC-Uruguai em função das doses de cálcio e da dose de $0,1 \mathrm{mg} \mathrm{L}^{-1}$ de boro na solução nutritiva. Média de quatro repetições.

\begin{tabular}{|c|c|c|c|c|c|c|c|c|c|}
\hline \multirow{5}{*}{$\begin{array}{c}\mathrm{Ca} \\
\left(\mathrm{mg} \mathrm{L}^{-1}\right)\end{array}$} & \multicolumn{8}{|c|}{ Concentração de boro $\left(\mathrm{mg} \mathrm{kg}^{-1}\right)$ e acúmulo de boro $(\mu \mathrm{g})$} & \multirow{5}{*}{$\begin{array}{l}\text { Acúmulo } \\
\text { total de } \\
\text { boro }(\mu \mathrm{g})\end{array}$} \\
\hline & \multicolumn{8}{|c|}{$\mathrm{B}\left(\mathrm{mg} \mathrm{L}^{-1}\right)$} & \\
\hline & \multicolumn{8}{|c|}{0,1} & \\
\hline & \multicolumn{2}{|c|}{ FS } & \multicolumn{2}{|c|}{ FI } & \multicolumn{2}{|c|}{$\mathrm{CS}$} & \multicolumn{2}{|c|}{$\mathrm{CI}$} & \\
\hline & $\mathrm{C}$ & A & $\mathrm{C}$ & A & $\mathrm{C}$ & A & $\mathrm{C}$ & A & \\
\hline 0 & 27,30 & 253,58 & 75,38 & 148,65 & 27,55 & 77,47 & 19,63 & 150,02 & 629,72 \\
\hline 50 & 24,10 & 289,89 & 99,38 & 212,06 & 27,88 & 102,40 & 14,63 & 143,27 & 747,62 \\
\hline 100 & 25,78 & 280,72 & 83,43 & 138,02 & 18,10 & 56,18 & 12,68 & 133,46 & 608,38 \\
\hline 200 & 12,40 & 156,50 & 48,15 & 144,09 & 21,28 & 75,06 & 13,83 & 143,92 & 519,57 \\
\hline 250 & 16,53 & 192,42 & 99,25 & 272,77 & 16,08 & 50,32 & 12,28 & 115,82 & 631,33 \\
\hline 300 & 14,33 & 161,57 & 72,05 & 267,99 & 15,65 & 45,77 & 11,08 & 122,56 & 597,89 \\
\hline
\end{tabular}

Tabela 10 - Concentração de boro no material vegetal seco (C) e acúmulo de boro (A) nas várias partes da planta da variedade IAC-Uruguai em função das doses de cálcio e da dose de $0,5 \mathrm{mg} \mathrm{L}^{-1}$ de boro na solução nutritiva. Média de quatro repetições.

\begin{tabular}{|c|c|c|c|c|c|c|c|c|c|}
\hline \multirow{5}{*}{$\begin{array}{c}\mathrm{Ca} \\
\left(\mathrm{mg} \mathrm{L}^{-1}\right)\end{array}$} & \multicolumn{8}{|c|}{ Concentração de boro $\left(\mathrm{mg} \mathrm{kg}^{-1}\right)$ e acúmulo de boro $(\mu \mathrm{g})$} & \multirow{3}{*}{$\begin{array}{l}\text { Acúmulo } \\
\text { total de }\end{array}$} \\
\hline & \multicolumn{8}{|c|}{$\mathrm{B}\left(\mathrm{mg} \mathrm{L}^{-1}\right)$} & \\
\hline & \multicolumn{8}{|c|}{0,5} & \\
\hline & \multicolumn{2}{|c|}{ FS } & \multicolumn{2}{|c|}{ FI } & \multicolumn{2}{|c|}{ CS } & \multicolumn{2}{|c|}{$\mathrm{CI}$} & boro $(\mu g)$ \\
\hline & $\mathrm{C}$ & A & $\mathrm{C}$ & A & $\mathrm{C}$ & A & $\mathrm{C}$ & A & \\
\hline 0 & 79,83 & 713,68 & 191,40 & 541,27 & 39,15 & 98,63 & 18,83 & 161,81 & 1515,39 \\
\hline 50 & 84,45 & 744,76 & 111,00 & 491,45 & 26,75 & 90,25 & 17,95 & 296,86 & 1623,32 \\
\hline 100 & 69,65 & 589,93 & 137,45 & 553,35 & 25,00 & 90,19 & 16,20 & 258,28 & 1491,75 \\
\hline 200 & 42,20 & 430,85 & 154,58 & 920,69 & 22,95 & 85,18 & 12,20 & 248,95 & 1685,67 \\
\hline 250 & 54,85 & 487,29 & 114,38 & 664,05 & 26,23 & 89,96 & 9,25 & 158,62 & 1399,92 \\
\hline 300 & 58,68 & 693,55 & 139,53 & 901,84 & 27,55 & 97,29 & 15,38 & 292,51 & 1985,19 \\
\hline
\end{tabular}


Tabela 11 - Concentração de boro no material vegetal seco (C) e acúmulo de boro (A) nas várias partes da planta do híbrido Rumbossol-91 em função das doses de cálcio e da dose de $0,1 \mathrm{mg} \mathrm{L}^{-1}$ de boro na solução nutritiva. Média de quatro repetições.

\begin{tabular}{|c|c|c|c|c|c|c|c|c|c|}
\hline \multirow{5}{*}{$\begin{array}{c}\mathrm{Ca} \\
\left(\mathrm{mg} \mathrm{L}^{-1}\right)\end{array}$} & \multicolumn{8}{|c|}{ Concentração de boro $\left(\mathrm{mg} \mathrm{kg}^{-1}\right)$ e acúmulo de boro $(\mu \mathrm{g})$} & \multirow{5}{*}{$\begin{array}{l}\text { Acúmulo } \\
\text { total de } \\
\text { boro }(\mu \mathrm{g})\end{array}$} \\
\hline & \multicolumn{8}{|c|}{$\mathrm{B}\left(\mathrm{mg} \mathrm{L}^{-1}\right)$} & \\
\hline & \multicolumn{8}{|c|}{0,1} & \\
\hline & \multicolumn{2}{|c|}{ FS } & \multicolumn{2}{|c|}{ FI } & \multicolumn{2}{|c|}{ CS } & \multicolumn{2}{|c|}{$\mathrm{Cl}$} & \\
\hline & $\mathrm{C}$ & A & $\mathrm{C}$ & A & $\mathrm{C}$ & A & $\mathrm{C}$ & A & \\
\hline 0 & 21,48 & 208,77 & 65,14 & 150,06 & 28,78 & 54,35 & 19,91 & 92,40 & 505,58 \\
\hline 50 & 21,43 & 225,32 & 54,86 & 140,22 & 17,75 & 51,22 & 7,20 & 71,24 & 488,00 \\
\hline 100 & 8,93 & 111,79 & 33,49 & 95,09 & 17,80 & 44,32 & 6,93 & 67,28 & 318,48 \\
\hline 200 & 10,68 & 147,19 & 39,36 & 122,96 & 16,29 & 41,92 & 12,53 & 118,04 & 430,11 \\
\hline 250 & 34,10 & 454,78 & 86,98 & 296,01 & 33,15 & 83,23 & 17,98 & 158,47 & 991,89 \\
\hline 300 & 29,13 & 430,59 & 80,96 & 303,26 & 31,14 & 97,16 & 26,27 & 246,40 & 1077,41 \\
\hline
\end{tabular}

Tabela 12 - Concentração de boro no material vegetal seco $(\mathrm{C})$ e acúmulo de boro $(\mathrm{A})$ nas várias partes da planta do híbrido Rumbossol-91 em função das doses de cálcio e da dose de $0,5 \mathrm{mg} \mathrm{L}^{-1}$ de boro na solução nutritiva. Média de quatro repetições.

\begin{tabular}{|c|c|c|c|c|c|c|c|c|c|}
\hline \multirow{5}{*}{$\begin{array}{c}\mathrm{Ca} \\
\left(\mathrm{mg} \mathrm{L}^{-1}\right)\end{array}$} & \multicolumn{8}{|c|}{ Concentração de boro $\left(\mathrm{mg} \mathrm{kg}^{-1}\right)$ e acúmulo de boro $(\mu \mathrm{g})$} & \multirow{5}{*}{$\begin{array}{l}\text { Acúmulo } \\
\text { total de } \\
\text { boro }(\mu \mathrm{g})\end{array}$} \\
\hline & \multicolumn{8}{|c|}{$B\left(\mathrm{mg} \mathrm{L}^{-1}\right)$} & \\
\hline & \multicolumn{8}{|c|}{0,5} & \\
\hline & \multicolumn{2}{|c|}{$\mathrm{FS}$} & \multicolumn{2}{|c|}{ FI } & \multicolumn{2}{|c|}{$\mathrm{CS}$} & \multicolumn{2}{|c|}{$\mathrm{CI}$} & \\
\hline & $\mathrm{C}$ & A & $\mathrm{C}$ & A & $\mathrm{C}$ & A & $\mathrm{C}$ & A & \\
\hline 0 & 61,14 & 617,78 & 117,03 & 358,78 & 30,46 & 78,87 & 16,50 & 140,40 & 1195,83 \\
\hline 50 & 75,21 & 652,61 & 138,84 & 596,20 & 28,51 & 72,32 & 10,66 & 137,59 & 1458,72 \\
\hline 100 & 65,63 & 700,66 & 110,32 & 440,80 & 20,40 & 57,29 & 6,93 & 100,10 & 1298,85 \\
\hline 200 & 53,89 & 646,25 & 127,06 & 701,33 & 40,43 & 122,22 & 15,62 & 236,67 & 1706,47 \\
\hline 250 & 58,10 & 636,21 & 142,93 & 750,82 & 30,73 & 88,26 & 16,12 & 233,51 & 1708,80 \\
\hline 300 & 62,57 & 727,06 & 130,12 & 847,40 & 41,08 & 132,30 & 26,16 & 461,76 & 2168,52 \\
\hline
\end{tabular}


Nas Tabelas 9, 10, 11 e 12 notam-se que os conteúdos totais de boro na variedade IAC-Unuguai foram maiores quando comparados com o híbrido Rumbossol-91 nos tratamentos com doses de cálcio inferiores a $200 \mathrm{mg} \mathrm{L}^{-1}$. A situação se inverteu para os tratamentos com doses maiores que as recomendadas por Sarruge (1975). O menor acúmulo de boro pode estar relacionado com cultivares que apresentam comportamentos diferentes quanto a exigência em boro. Hu et al. (1996) relataram que a variabilidade entre as espécies de plantas no requerimento de boro está relacionado com o conteúdo de pectina da parede celular.

Os dados das Tabelas 9 e 11 evidenciam que os tratamentos com doses decrescentes de cálcio e com doses de $0,1 \mathrm{mg} \mathrm{L}^{-1}$ de $\mathrm{B}$ provocaram, no geral, aumento nas concentrações de boro nas partes aéreas das plantas, indicando "efeito de concentração", isto é, o menor desenvolvimento das plantas resultou em maior concentração do nutriente nos tecidos. Dados semelhantes foram encontrados por Baumgartner et al. (1986).

\section{Folhas superiores}

O acúmulo de boro nas folhas superiores não apresentou significância para o estudo de regressões no híbrido Rumbossol-91 quando submetido a dose de 0,5 $\mathrm{mg} \mathrm{L}^{-1}$ de B (Figura 13). Isso indica que diferentes doses de cálcio não interfiriram nas quantidades de boro absorvidas pelas folhas superiores das plantas de girassol.

O híbrido Rumbossol-91 apresentou resposta quadrática quando fornecida a dose de $0,1 \mathrm{mg} \mathrm{L}^{-1}$ de $\mathrm{B}$ na solução nutritiva, obtendo-se um ponto de mínimo acúmulo numa dose estimada de $125 \mathrm{mg} \mathrm{kg}^{-1}$ de Ca (Figura 13). Nas doses maiores houve aumento no acúmulo de boro nas folhas superiores.

O acúmulo de boro para a variedade IAC-Uruguai apresentou resposta linear para a dose de $0,1 \mathrm{mg} \mathrm{L}^{-1}$ de $\mathrm{B}$, não atingindo um ponto de mínimo. Quanto maiores as doses de cálcio fornecidas, menores foram as quantidades de boro absorvidas. Dados semelhantes foram encontrados por Tanaka $(1967)^{5}$, citado por Gupta e MacLeod

\footnotetext{
${ }^{5}$ Tanaka, H. Boron absorption by crop plants as affected by other nutrients of the medium. Soil Science Plant Nutrition, v.13, p.41-44, 1967.
} 
(1977), que observou menor absorção de boro quanto maior a dose de cálcio fornecida para rabanete. Drake et al. (1941), em estudos com tabaco, observaram que em solos com elevado teor de cálcio ocorreram plantas com deficiência de boro. Dados semelhantes também são relatados por Reeve \& Shive (1944).

Os dados responderam segundo modelo quadrático para o cultivar IAC-Uruguai quando submetida ao tratamento com $0,5 \mathrm{mg} \mathrm{L}^{-1}$ de $\mathrm{B}$. O ponto de mínimo acúmulo para esse cultivar foi de 42,20 $\mu \mathrm{g}$ de B na dose de $200 \mathrm{mg} \mathrm{L}^{-1}$ de Ca.

A diferença de comportamento entre os dois cultivares pode ser explicada devido as diferentes capacidades de extração do boro.

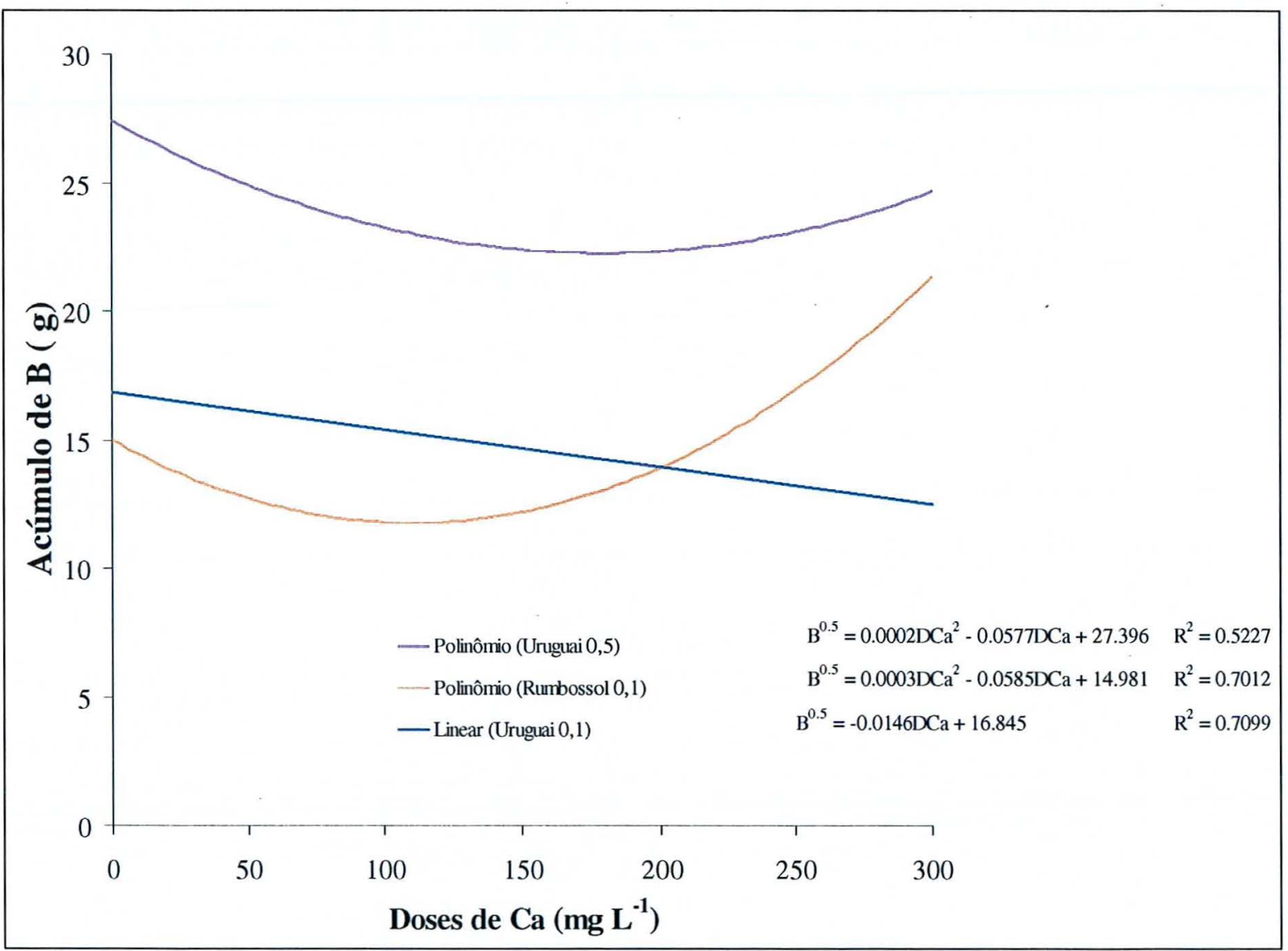

Figura 13 - Acúmulo de B nas folhas superiores de dois cultivares de girassol (IACUruguai e Rumbossol-91) em função das doses de cálcio e boro na solução nutritiva. Média de quatro repetições. 


\section{Folhas inferiores}

Na Figura 14, podemos observar que o cultivar IAC-Uruguai apresentou resposta linear nas duas doses de boro não atingindo um ponto máximo de boro acumulado. $\mathrm{O}$ mesmo acontece para o híbrido Rumbossol-91 submetido a dose de $0,5 \mathrm{mg} \mathrm{L}^{-1}$ de $\mathrm{B}$. Para a dose de $0,1 \mathrm{mg} \mathrm{L}^{-1}$ de $\mathrm{B}$, o híbrido apresentou resposta quadrática com ponto de mínimo de 95,09 $\mu \mathrm{g}$ de B absorvido.

Nas doses de cálcio mais elevadas, nota-se maior acúmulo de boro nas folhas superiores de girassol dos cultivares IAC-Uruguai e Rumbossol-91.

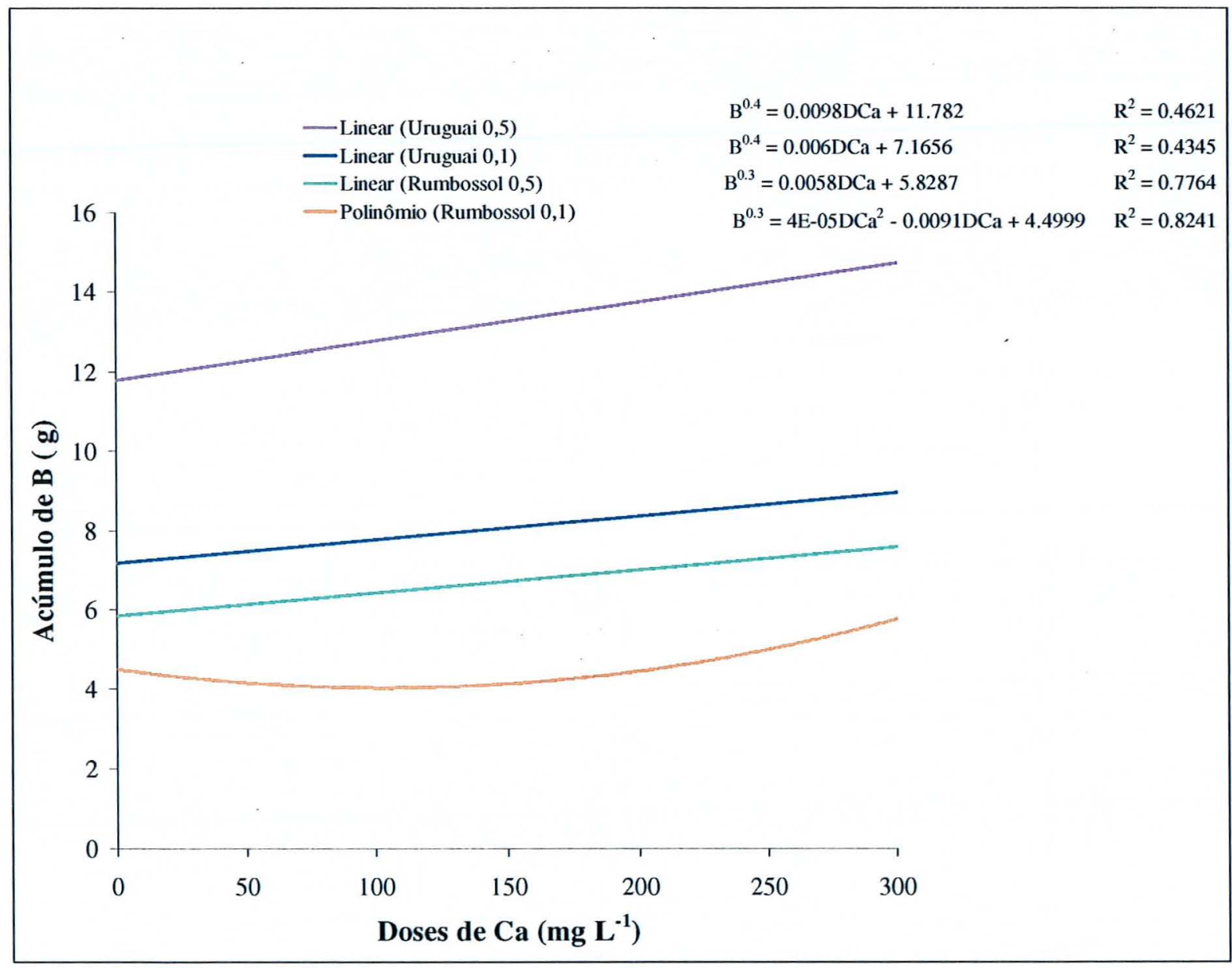

Figura 14 - Acúmulo de B nas folhas inferiores de dois cultivares de girassol (IACUruguai e Rumbossol-91) em função das doses de cálcio e boro na solução nutritiva. Média de quatro repetições. 
Nas Tabelas 9, 10, 11 e 12 e nas Figuras 13 e 14, notam-se maiores acúmulos de boro em folhas novas quando as doses de cálcio na solução nutritiva foram inferiores as recomendadas por Sarruge (1975). A partir da dose de $200 \mathrm{mg} \mathrm{L}^{-1}$ de Ca e $0,5 \mathrm{mg} \mathrm{L}^{-1}$ de B (tratamento 8), o acúmulo tornou-se superior nas folhas inferiores concordando com Shelp et al. (1995). Estas observações sugerem que o boro é translocado principalmente pelo fluxo transpiratório em condições nutricionais adequadas, concordando com Kohl \& Oertli (1961). No híbrido Rumbossol-91, somente nos tratamentos com suprimento adequado de boro $\left(0,5 \mathrm{mg} \mathrm{L}^{-1}\right)$ houve maior acúmulo nas folhas inferiores, sugerindo que este cultivar é mais exigente em boro quando comparado com a variedade IACUruguai.

Segundo Brown \& Shelp (1997), a retranslocação do boro é evidenciada pela diminuição da concentração do boro em folhas maduras de várias culturas. Analisando os dados apresentados nas Tabelas 9, 10,11 e 12 podemos notar maior concentração de boro nas folhas inferiores evidenciando a baixa retranslocação do boro em plantas de girassol.

\section{Caules superiores}

$\mathrm{O}$ acúmulo de boro nos caules superiores não apresentou significância para o estudo de regressões na variedade IAC-Uruguai quando submetida a dose de $0,5 \mathrm{mg} \mathrm{L}^{-1}$ de $\mathrm{B}$ (Figura 15). Na mesma variedade com a dose de $0,1 \mathrm{mg} \mathrm{L}^{-1}$ de B obteve-se resposta linear sem atingir um ponto de mínimo acúmulo de boro.

$\mathrm{Na}$ Figura 15, notam-se respostas diferentes para a quantidade de boro acumulada em relação às doses de cálcio oferecidas. Para o híbrido Rumbossol-91 submetido à dose de $0,1 \mathrm{mg} \mathrm{L}^{-1}$ de $\mathrm{B}$ verificou-se resposta quadrática com ponto de mínimo estimado em $41,92 \mathrm{mg} \mathrm{kg}^{-1}$ de $\mathrm{B}$ na dose de $200 \mathrm{mg} \mathrm{L}^{-1} \mathrm{de} \mathrm{Ca}$. 


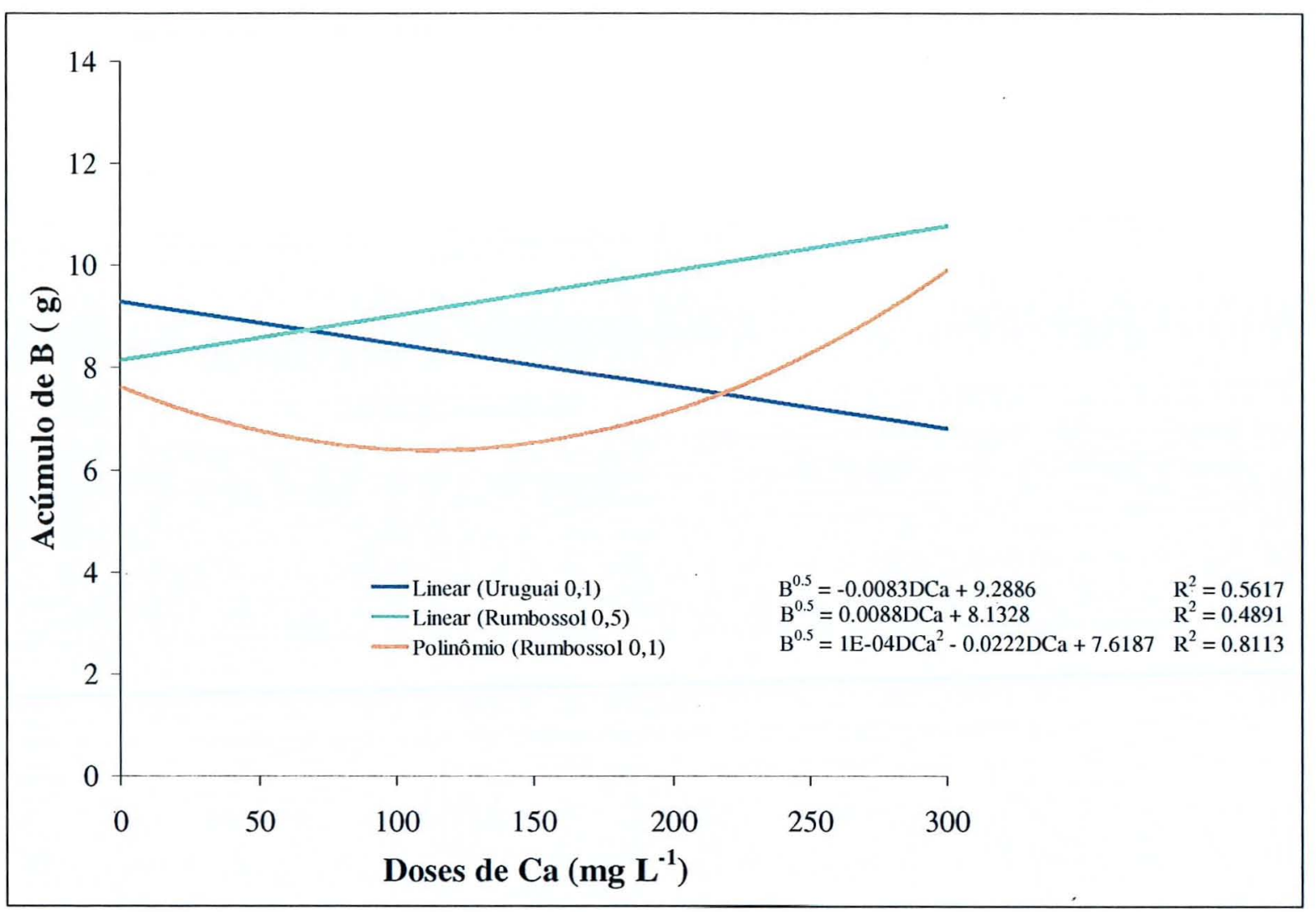

Figura 15 - Acúmulo de B nos caules superiores de dois cultivares de girassol (IACUruguai e Rumbossol-91) em função das doses de cálcio e boro na solução nutritiva. Média de quatro repetições.

\section{Caules inferiores}

Os acúmulos de boro em função das doses de cálcio e boro nos caules inferiores para o cultivar IAC-Uruguai não foram significativos em nenhuma dose de boro oferecida.

De acordo com a Figura 16, o híbrido Rumbossol-91 apresentou resposta linear para as duas doses de boro, obtendo-se maiores acúmulos quando ofertou-se 0,5 $\mathrm{mg} \mathrm{L}^{-1}$ de B na solução nutritiva. 


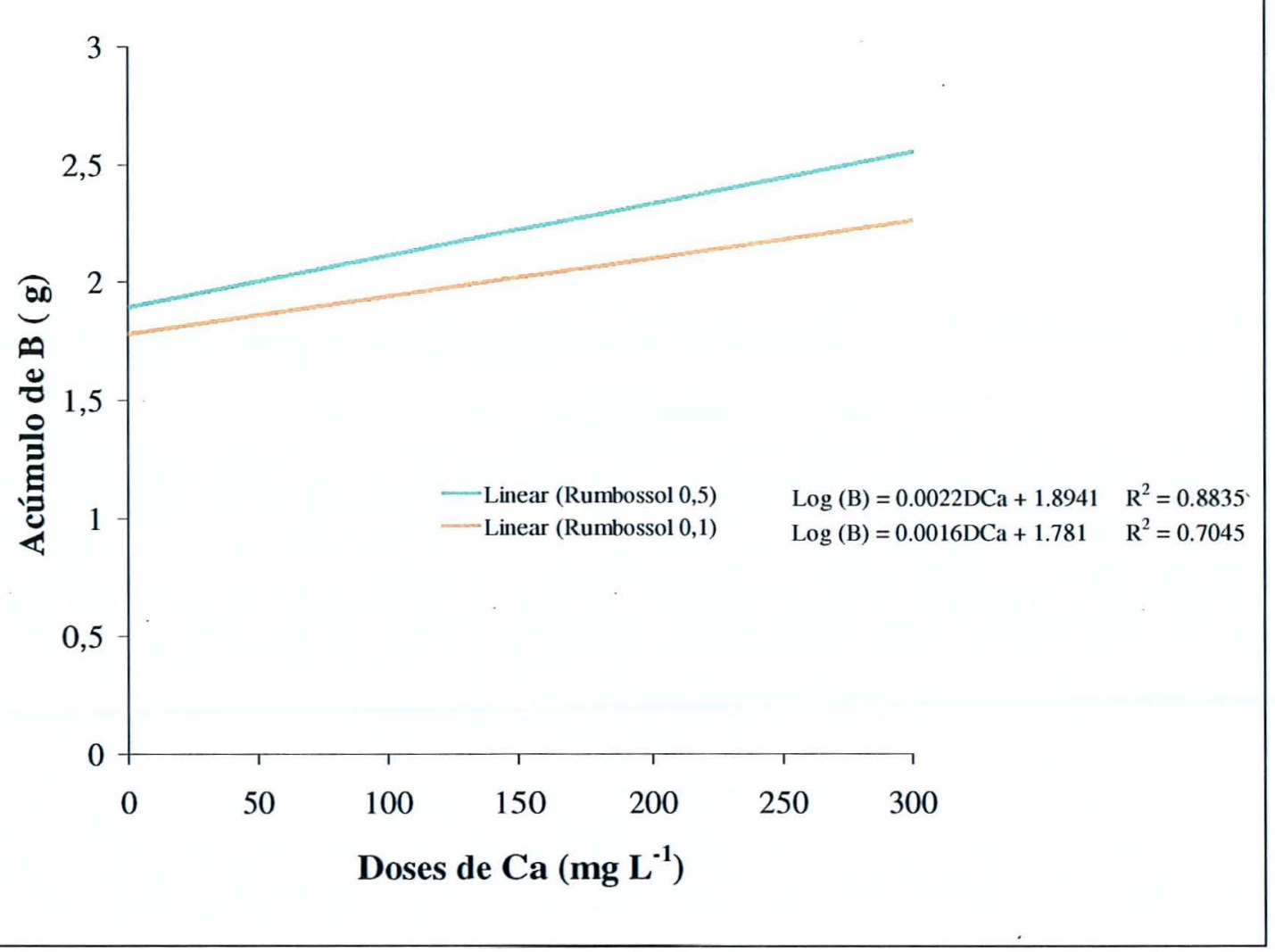

Figura 16 - Acúmulo de B nos caules inferiores do cultivar Rumbossol-91 em função das doses de cálcio e boro na solução nutritiva. Média de quatro repetições.

Nas Tabelas 9, 10, 11 e 12 são apresentados os acúmulos de boro nas várias partes das plantas e nota-se que as folhas apresentaram maiores quantidades acumuladas que os caules, concordando com Sfredo (1984) e Rossi (1998).

Na Figura 16 observa-se maiores acúmulos de boro nos tratamentos com 0,5 mg $\mathrm{L}^{-1}$ de $\mathrm{B}$ para os dois cultivares de girassol estudados. De acordo o fornecimento de maiores doses de cálcio, maiores foram os acúmulos de boro na parte aérea das plantas de girassol quando supridas adequadamente com boro. 


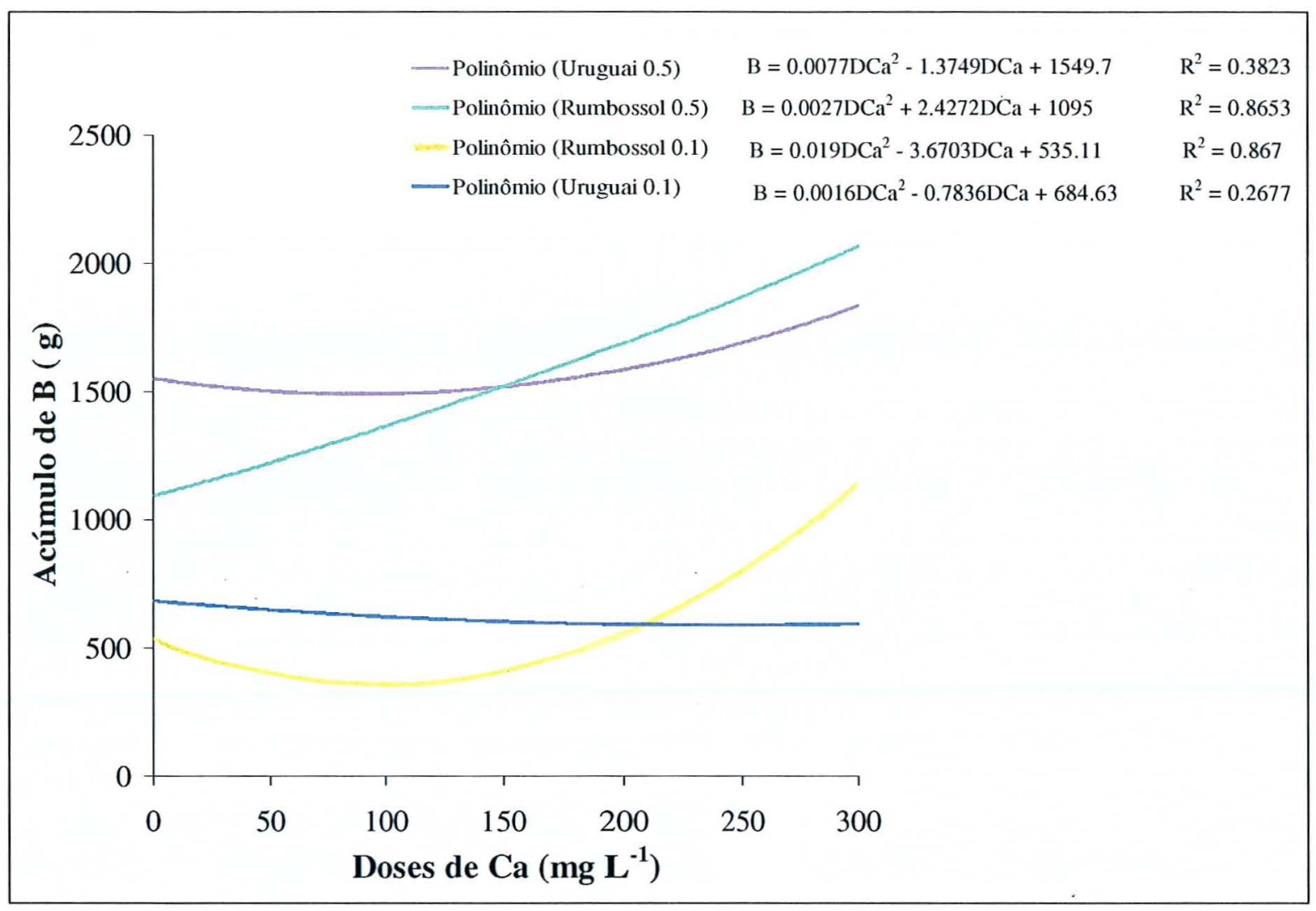

Figura 17 - Acúmulo de B na parte aérea de dois cultivares de girassol (IAC-Uruguai e Rumbossol-91) em função das doses de cálcio e boro na solução nutritiva. Média de quatro repetições.

\subsubsection{Concentração e acúmulo de cálcio nas partes das plantas}

Nas Tabelas 13, 14, 15 e 16 verificam-se diferenças em relação ao acúmulo dos nutrientes. Quanto maior a quantidade de cálcio fornecida na solução nutritiva, maior foi a concentração deste nutriente nas partes das plantas, concordando com dados de Esteban et al. (1997). De acordo com trabalhos de Yamauchi et al. (1986) e Esteban et al. (1997), verificou-se que a quantidade total de cálcio absorvida não foi afetada pela deficiência de boro $\left(0,1 \mathrm{mg} \mathrm{L}^{-1}\right)$. 
Tabela 13 - Concentração de cálcio no material vegetal seco (C) e acúmulo de cálcio (A) nas várias partes da planta da variedade IAC-Uruguai em função das doses de cálcio e da dose de $0,1 \mathrm{mg} \mathrm{L}^{-1}$ de boro na solução nutritiva. Média de quatro repetições.

\begin{tabular}{|c|c|c|c|c|c|c|c|c|c|}
\hline \multirow{5}{*}{$\begin{array}{c}\mathrm{Ca} \\
\left(\mathrm{mg} \mathrm{L}^{-1}\right)\end{array}$} & \multicolumn{8}{|c|}{ Concentração de cálcio $\left(\mathrm{g} \mathrm{kg}^{-1}\right)$ e acúmulo de cálcio (mg ) } & \multirow{5}{*}{$\begin{array}{l}\text { Acúmulo } \\
\text { total de } \\
\text { cálcio (mg) }\end{array}$} \\
\hline & \multicolumn{8}{|c|}{$\mathrm{B}\left(\mathrm{mg} \mathrm{L}^{-1}\right)$} & \\
\hline & \multicolumn{8}{|c|}{0,1} & \\
\hline & \multicolumn{2}{|c|}{ FS } & \multicolumn{2}{|c|}{ FI } & \multicolumn{2}{|c|}{$\mathrm{CS}$} & \multicolumn{2}{|c|}{$\mathrm{CI}$} & \\
\hline & $\mathrm{C}$ & A & $\mathrm{C}$ & A & $\mathrm{C}$ & A & $\mathrm{C}$ & A & \\
\hline 0 & 6,53 & 66,80 & 14,64 & 30,46 & 3,92 & 11,02 & 2,47 & 21,69 & 129,97 \\
\hline 50 & 6,00 & 71,79 & 15,44 & 33,17 & 4,37 & 16,05 & 2,65 & 27,12 & 148,13 \\
\hline 100 & 8,27 & 109,99 & 17,15 & 36,95 & 6,61 & 19,31 & 6,81 & 31,61 & 197,86 \\
\hline 200 & 14,42 & 181,41 & 35,96 & 105,77 & 6,89 & 24,18 & 3,97 & 41,02 & 352,38 \\
\hline 250 & 17,78 & 208,57 & 23,57 & 69,48 & 8,11 & 25,07 & 5,39 & 50,64 & 353,76 \\
\hline 300 & 19,57 & 216,05 & 43,35 & 155,57 & 9,68 & 27,91 & 5,64 & 64,09 & 463,62 \\
\hline
\end{tabular}

Tabela 14 - Concentração de cálcio no material vegetal seco (C) e acúmulo de cálcio (A) nas várias partes da planta da variedade IAC-Uruguai em função das doses de cálcio e da dose de $0,5 \mathrm{mg} \mathrm{L}^{-1}$ de boro na solução nutritiva. Média de quatro repetições.

\begin{tabular}{|c|c|c|c|c|c|c|c|c|c|}
\hline \multirow{5}{*}{$\begin{array}{c}\mathrm{Ca} \\
\left(\mathrm{mg} \mathrm{L}^{-1}\right)\end{array}$} & \multicolumn{8}{|c|}{ Concentração de cálcio $\left(\mathrm{g} \mathrm{kg}^{-1}\right)$ e acúmulo de cálcio $(\mathrm{mg})$} & \multirow{5}{*}{$\begin{array}{l}\text { Acúmulo } \\
\text { total de } \\
\text { cálcio }(\mathrm{mg})\end{array}$} \\
\hline & \multicolumn{8}{|c|}{$\mathrm{B}\left(\mathrm{mg} \mathrm{L}^{-1}\right)$} & \\
\hline & \multicolumn{8}{|c|}{0,5} & \\
\hline & \multicolumn{2}{|c|}{ FS } & \multicolumn{2}{|c|}{ FI } & \multicolumn{2}{|c|}{$\mathrm{CS}$} & \multicolumn{2}{|c|}{$\mathrm{CI}$} & \\
\hline & $\mathrm{C}$ & A & $\mathrm{C}$ & A & $\mathrm{C}$ & A & $\mathrm{C}$ & A & \\
\hline 0 & 4,34 & 41,73 & 9,74 & 33,16 & 8,06 & 24,22 & 3,52 & 50,54 & 149,65 \\
\hline 50 & 8,17 & 75,02 & 14,07 & 67,29 & 5,08 & 16,84 & 3,71 & 60,99 & 220,14 \\
\hline 100 & 9,44 & 80,89 & 16,40 & 64,94 & 5,70 & 20,27 & 2,96 & 47,66 & 213,76 \\
\hline 200 & 10,64 & 111,89 & 20,87 & 126,17 & 6,80 & 25,18 & 3,53 & 71,32 & 34,56 \\
\hline 250 & 18,81 & 180,61 & 26,45 & 148,51 & 13,42 & 45,37 & 4,80 & 83,20 & 457,69 \\
\hline 300 & 17,84 & 207,90 & 27,03 & 175,57 & 12,17 & 43,41 & 4,69 & 87,98 & 514,86 \\
\hline
\end{tabular}


Tabela 15 - Concentração de cálcio no material vegetal seco (C) e acúmulo de cálcio (A) nas várias partes da planta do híbrido Rumbossol-91 em função das doses de cálcio e da dose de $0,1 \mathrm{mg} \mathrm{L}^{-1}$ de boro na solução nutritiva. Média de quatro repetições.

\begin{tabular}{|c|c|c|c|c|c|c|c|c|c|}
\hline \multirow{5}{*}{$\begin{array}{c}\mathrm{Ca} \\
\left(\mathrm{mg} \mathrm{L}^{-1}\right)\end{array}$} & \multicolumn{8}{|c|}{ Concentração de cálcio $\left(\mathrm{g} \mathrm{kg}^{-1}\right)$ e acúmulo de cálcio $(\mathrm{mg})$} & \multirow{5}{*}{$\begin{array}{l}\text { Acúmulo } \\
\text { total de } \\
\text { cálcio (mg) }\end{array}$} \\
\hline & \multicolumn{8}{|c|}{$\mathrm{B}\left(\mathrm{mg} \mathrm{L}^{-1}\right)$} & \\
\hline & \multicolumn{8}{|c|}{0,1} & \\
\hline & \multicolumn{2}{|c|}{ FS } & \multicolumn{2}{|c|}{ FI } & \multicolumn{2}{|c|}{ CS } & \multicolumn{2}{|c|}{$\mathrm{CI}$} & \\
\hline & $\mathrm{C}$ & A & $\mathrm{C}$ & A & $\mathrm{C}$ & A & $\mathrm{C}$ & A & \\
\hline 0 & 2,60 & 29,39 & 10,91 & 26,02 & 1,89 & 3,99 & 1,31 & 7,66 & 67,06 \\
\hline 50 & 6,36 & 75,12 & 11,90 & 33,09 & 3,72 & 11,06 & 2,14 & 20,85 & 140,12 \\
\hline 100 & 9,72 & 122,26 & 19,72 & 59,63 & 5,19 & 13,02 & 2,33 & 22,77 & 217,68 \\
\hline 200 & 16,89 & 232,03 & 26,26 & 87,18 & 7,09 & 20,24 & 2,99 & 28,32 & 367,77 \\
\hline 250 & 16,20 & 216,76 & 30,40 & 110,70 & 7,42 & 18,72 & 3,65 & 31,70 & 377,88 \\
\hline 300 & 18,20 & 275,89 & 33,27 & 124,13 & 6,79 & 21,21 & 3,06 & 28,59 & 449,82 \\
\hline
\end{tabular}

Tabela 16 - Concentração de cálcio no material vegetal seco (C) e acúmulo de cálcio (A) nas várias partes da planta do híbrido Rumbossol-91 em função das doses de cálcio e da dose de $0,5 \mathrm{mg} \mathrm{L}^{-1}$ de boro na solução nutritiva. Média de quatro repetições.

\begin{tabular}{|c|c|c|c|c|c|c|c|c|c|}
\hline \multirow{5}{*}{$\begin{array}{c}\mathrm{Ca} \\
\left(\mathrm{mg} \mathrm{L}^{-1}\right)\end{array}$} & \multicolumn{8}{|c|}{ Concentração de cálcio $\left(\mathrm{g} \mathrm{kg}^{-1}\right)$ e acúmulo de cálcio $(\mathrm{mg})$} & \multirow{5}{*}{$\begin{array}{l}\text { Acúmulo } \\
\text { total de } \\
\text { cálcio (mg) }\end{array}$} \\
\hline & \multicolumn{8}{|c|}{$\mathrm{B}\left(\mathrm{mg} \mathrm{L}^{-1}\right)$} & \\
\hline & \multicolumn{8}{|c|}{0,5} & \\
\hline & \multicolumn{2}{|c|}{ FS } & \multicolumn{2}{|c|}{$\mathrm{FI}$} & \multicolumn{2}{|c|}{ CS } & \multicolumn{2}{|c|}{$\mathrm{CI}$} & \\
\hline & $\mathrm{C}$ & A & $\mathrm{C}$ & A & $\mathrm{C}$ & A & $\mathrm{C}$ & A & \\
\hline 0 & 3,22 & 33,72 & 11,36 & 39,55 & 2,32 & 6,80 & 1,37 & 18,07 & 98,14 \\
\hline 50 & 3,35 & 29,15 & 8,73 & 37,27 & 2,52 & 6,21 & 1,60 & 21,25 & 93,88 \\
\hline 100 & 7,58 & 80,13 & 15,19 & 60,21 & 3,94 & 10,96 & 2,01 & 29,84 & 181,14 \\
\hline 200 & 12,82 & 152,05 & 22,41 & 122,94 & 7,14 & 21,50 & 2,42 & 36,15 & 332,64 \\
\hline 250 & 16,83 & 179,14 & 25,87 & 135,55 & 8,25 & 22,91 & 3,45 & 50,65 & 388,25 \\
\hline 300 & 13,95 & 161,36 & 24,99 & 164,29 & 6,80 & 21,89 & 3,09 & 55,10 & 402,64 \\
\hline
\end{tabular}




\section{Folhas superiores}

Na Figura 18, verifica-se que os acúmulos de cálcio nas folhas superiores foram maiores quanto maior foi a quantidade desse nutriente oferecida nas soluções nutritivas. Dados semelhantes foram relatados por Esteban et al. (1996) em estudos com amendoim. Nota-se que todas as respostas foram lineares, independente da dose de boro do tratamento.

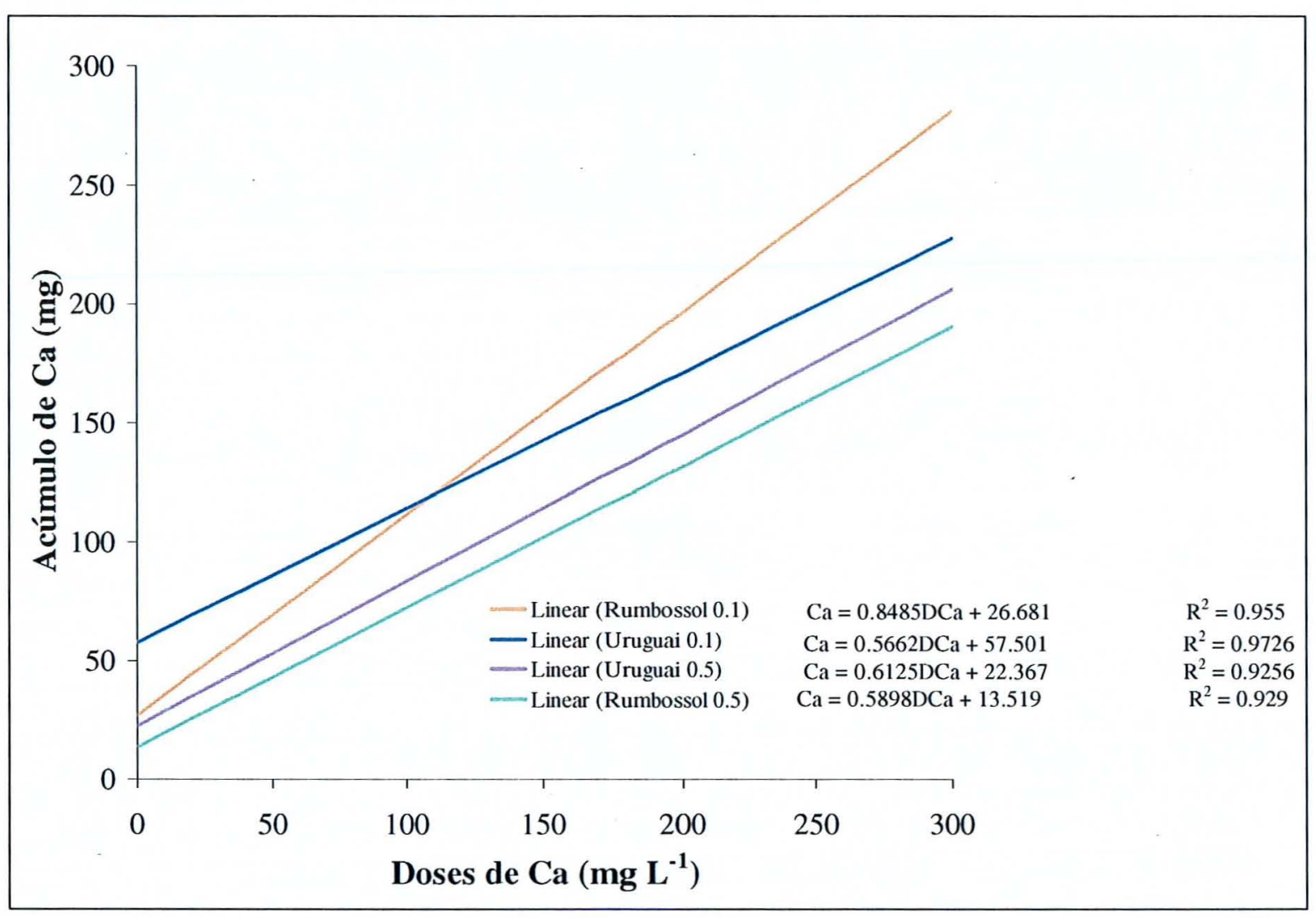

Figura 18 - Acúmulo de Ca nas folhas superiores de dois cultivares de girassol (IACUruguai e Rumbossol-91) em função das doses de cálcio e boro na solução nutritiva. Média de quatro repetições. 


\section{Folhas inferiores}

Para os dois cultivares verificam-se respostas lineares quanto à absorção de cálcio nas folhas inferiores (Figura 19).

O híbrido Rumbossol-91 apresentou maiores acúmulos de cálcio do que a variedade IAC-Uruguai. De acordo com a Figura 19, para ambos os cultivares, foi na dose de $0,5 \mathrm{mg} \mathrm{L}^{-1}$ de $\mathrm{B}$ que ocorreram maiores acúmulos de cálcio.

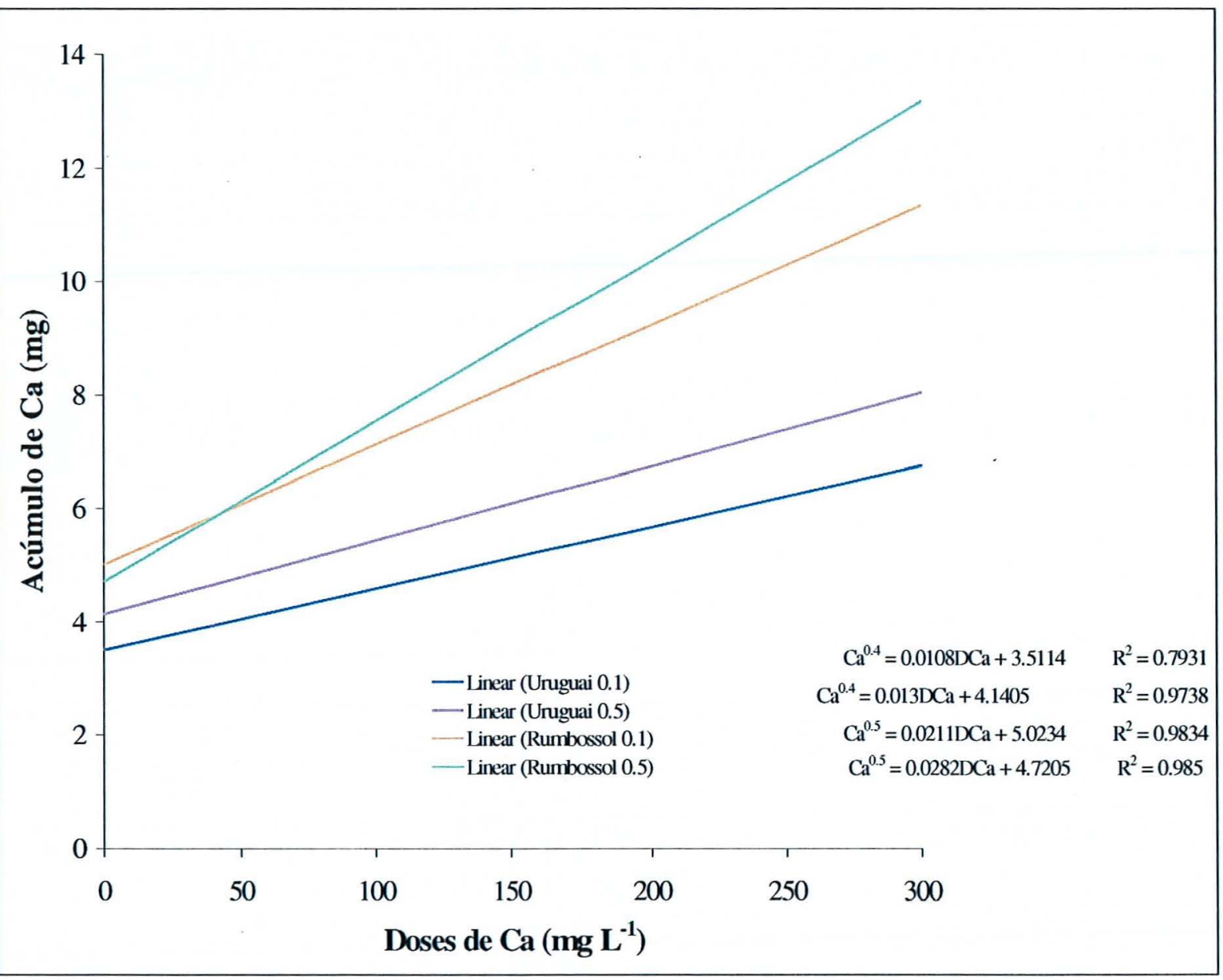

Figura 19 - Acúmulo de Ca nas folhas inferiores de dois cultivares de girassol (IACUruguai e Rumbossol-91) em função das doses de cálcio e boro na solução nutritiva. Média de quatro repetições. 


\section{Caules superiores}

Na Figura 20, podemos observar que respostas lineares foram obtidas para a variedade IAC-Uruguai submetida à dose de $0,5 \mathrm{mg} \mathrm{L}^{-1}$ de $\mathrm{B}$ que apresentou maior acúmulo de cálcio, e para o híbrido Rumbossol-91 submetido ao tratamento de 0,1 mg $\mathrm{L}^{-1}$ de $\mathrm{B}$ no substrato.

Respostas quadráticas foram observadas para a variedade IAC-Uruguai na dose de $0,1 \mathrm{mg} \mathrm{L}^{-1}$ de B e para o híbrido Rumbossol-91 submetido a dose de $0,5 \mathrm{mg} \mathrm{L}^{-1}$ de B.

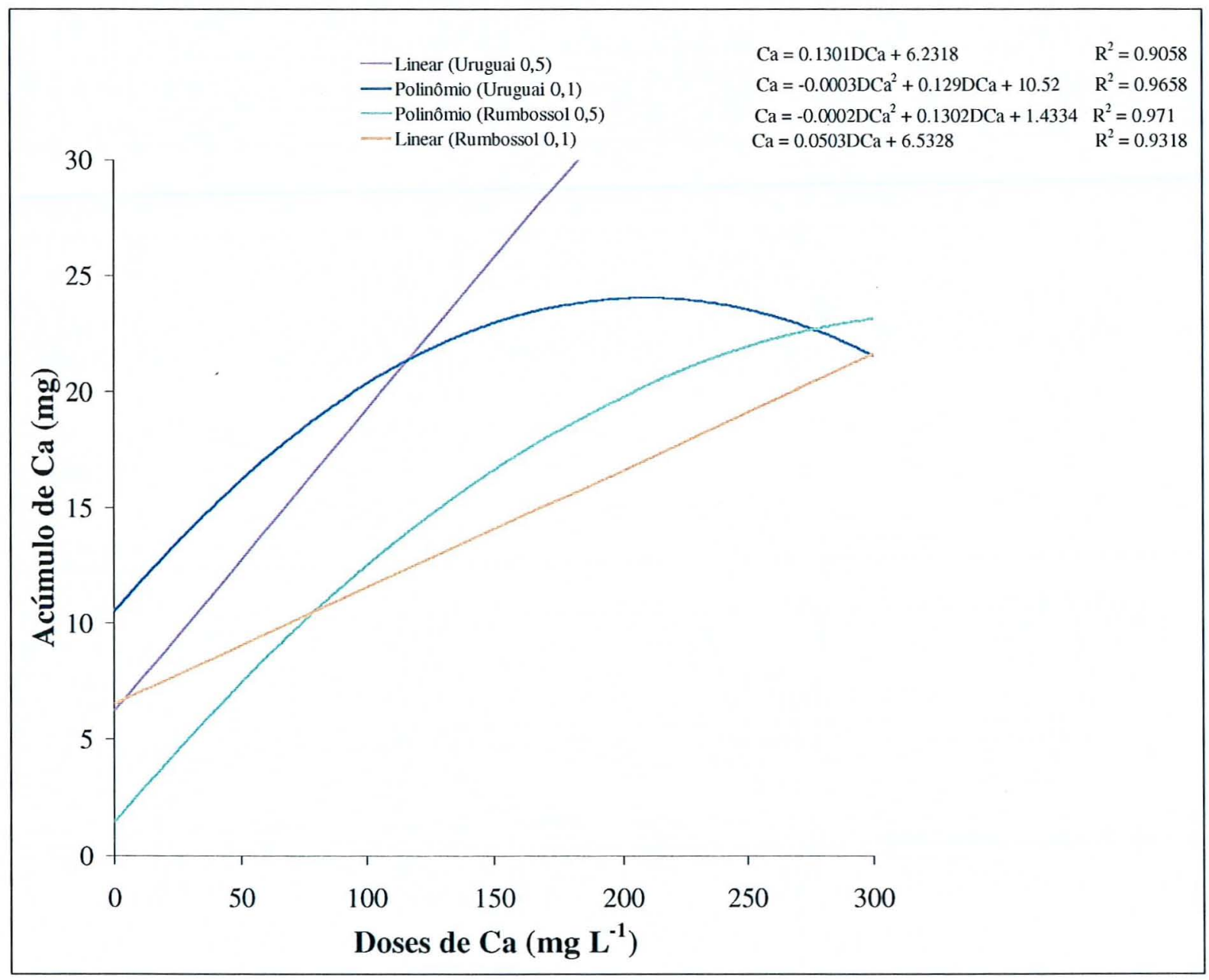

Figura 20 - Acúmulo de Ca nos caules superiores de dois cultivares de girassol (IACUruguai e Rumbossol-91) em função das doses de cálcio e boro na solução nutritiva. Média de quatro repetições. 


\section{Caules inferiores}

Assim como ocorreu nos caules superiores, nos caules inferiores também foi verificado o maior acúmulo de cálcio no cultivar IAC-Uruguai submetido à dose de 0,5 $\mathrm{mg} \mathrm{L}^{-1}$ de B (Figura 21).

Observou-se resposta quadrática apenas para o híbrido Rumbossol-91 no tratamento com $0,1 \mathrm{mg} \mathrm{L}^{-1}$ de $\mathrm{B}$, apresentando menor acúmulo de cálcio. Resultados semelhantes foram encontrados por Sfredo (1984), que relatou que aos 56 dias, as concentrações de cálcio nas folhas foram superiores às concentrações nos caules.

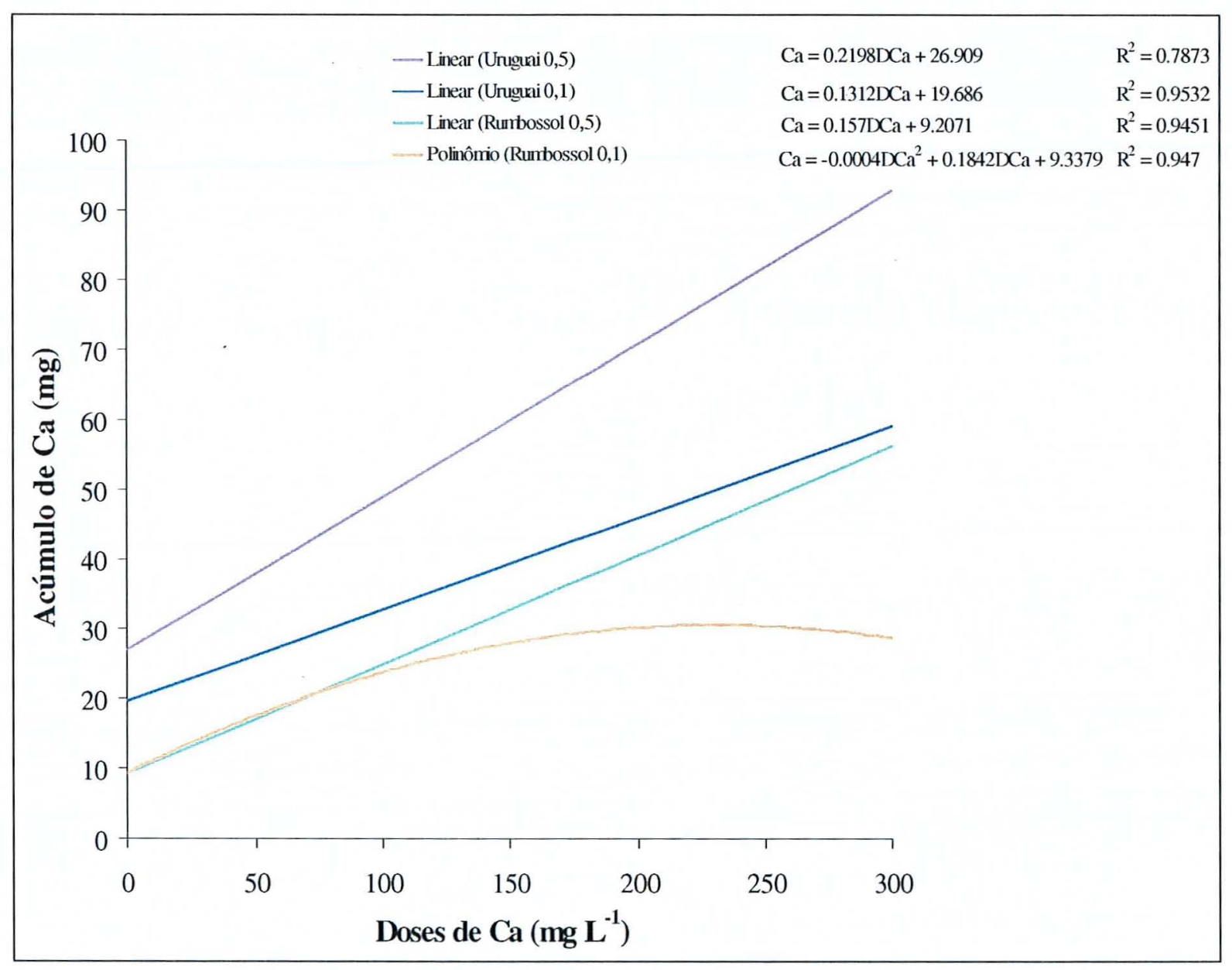

Figura 21 - Acúmulo de Ca nos caules inferiores de dois cultivares de girassol (IACUruguai e Rumbossol-91) em função das doses de cálcio e boro na solução nutritiva. Média de quatro repetições. 
A Figura 22 apresenta o acúmulo de cálcio na parte aérea dos cultivares de girassol em função das doses de cálcio e boro na solução nutritiva. Observou-se que quanto maior a dose de cálcio fornecida, maior o acúmulo desse nutriente na planta. Pouca influência das doses de boro foi observada na quantidade de cálcio acumulada.

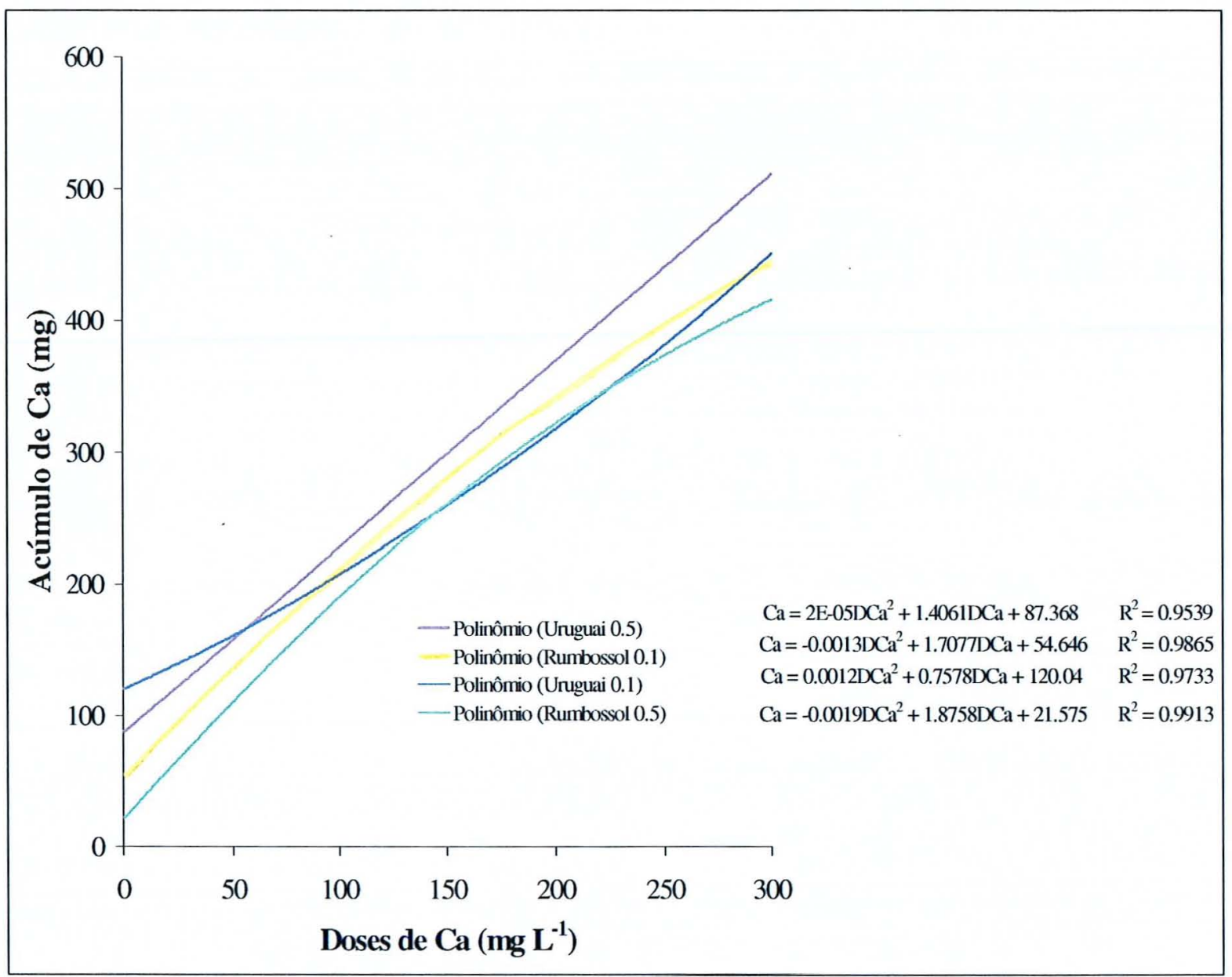

Figura 22 - Acúmulo de Ca na parte aérea de dois cultivares de girassol (IAC-Uruguai e Rumbossol-91) em função das doses de cálcio e boro na solução nutritiva. Média de quatro repetições. 


\subsection{Distribuição porcentual dos nutrientes acumulados nas partes das plantas}

Nas Tabelas 14 e 15, são apresentados os dados da distribuição porcentual do cálcio e do boro acumulados nas partes das plantas. Verificou-se que ocorreu maior acúmulo de cálcio e de boro nas folhas superiores na maioria dos tratamentos (Tabelas 17 e 18).

A partir dos tratamentos com doses de cálcio igual ou superior a $200 \mathrm{mg} \mathrm{L}^{-1}$ ocorreu maior acúmulo de boro nas folhas inferiores do que nas demais partes das plantas, mostrando que ocorre influência do cálcio na translocação do boro nas plantas de girassol dos cultivares IAC-Uruguai e Rumbossol-91.

Em órgãos que perdem pouca água pela transpiração, como os caules, a porcentagem do total de boro acumulado foi menor do que nas folhas, onde o fluxo transpiratório é mais ativo. Dados semelhantes foram encontrados por Dannel et al. (1999). 
Tabela 17 - Distribuição porcentual das quantidades de cálcio e boro acumuladas nas partes das plantas de girassol da variedade IAC-Uruguai. Média de quatro repetições.

\begin{tabular}{|c|c|c|c|c|c|}
\hline \multirow[b]{2}{*}{ Tratamentos } & \multirow[b]{2}{*}{ Nutrientes } & \multicolumn{4}{|c|}{ Parte da Planta } \\
\hline & & $\begin{array}{c}\text { Folhas } \\
\text { superiores }\end{array}$ & $\begin{array}{l}\text { Folhas } \\
\text { inferiores }\end{array}$ & $\begin{array}{c}\text { Caules } \\
\text { superiores }\end{array}$ & $\begin{array}{l}\text { Caules } \\
\text { Inferiores }\end{array}$ \\
\hline \multirow[t]{2}{*}{1} & $\mathrm{Ca}$ & 51,39 & 23,43 & 8,48 & 16,69 \\
\hline & $\mathrm{B}$ & 40,26 & 23,60 & 12,30 & 23,82 \\
\hline \multirow[t]{2}{*}{2} & $\mathrm{Ca}$ & 27,88 & 22,16 & 16,18 & 33,77 \\
\hline & $\mathrm{B}$ & 47,09 & 35,72 & 6,51 & 10,67 \\
\hline \multirow[t]{2}{*}{3} & $\mathrm{Ca}$ & 48,46 & 22,39 & 10,83 & 18,30 \\
\hline & $\mathrm{B}$ & 38,77 & 28,36 & 13,69 & 19,16 \\
\hline \multirow[t]{2}{*}{4} & $\mathrm{Ca}$ & 34,07 & 30,56 & 7,65 & 27,70 \\
\hline & $\mathrm{B}$ & 45,86 & 30,27 & 5,56 & 18,28 \\
\hline \multirow[t]{2}{*}{5} & $\mathrm{Ca}$ & 55,59 & 18,67 & 9,76 & 15,97 \\
\hline & $\mathrm{B}$ & 46,14 & 22,68 & 9,23 & 21,93 \\
\hline \multirow[t]{2}{*}{6} & $\mathrm{Ca}$ & 37,84 & 30,38 & 9,48 & 22,29 \\
\hline & $\mathrm{B}$ & 39,54 & 37,09 & 6,04 & 17,31 \\
\hline \multirow[t]{2}{*}{7} & $\mathrm{Ca}$ & 51,48 & 30,01 & 6,86 & 11,64 \\
\hline & B & 30,12 & 27,73 & 14,44 & 27,69 \\
\hline \multirow[t]{2}{*}{8} & $\mathrm{Ca}$ & 33,44 & 37,71 & 7,52 & 21,31 \\
\hline & $\mathrm{B}$ & 25,56 & 54,61 & 5,05 & 14,77 \\
\hline \multirow[t]{2}{*}{9} & $\mathrm{Ca}$ & 58,96 & 19,64 & 7,08 & 14,31 \\
\hline & B & 30,48 & 43,20 & 7,97 & 18,34 \\
\hline \multirow[t]{2}{*}{10} & $\mathrm{Ca}$ & 39,46 & 32,44 & 9,91 & 18,18 \\
\hline & B & 34,80 & 47,43 & 6,42 & 11,33 \\
\hline \multirow[t]{2}{*}{11} & $\mathrm{Ca}$ & 46,60 & 33,55 & 6,02 & 13,82 \\
\hline & B & 27,02 & 44,82 & 7,65 & 20,49 \\
\hline \multirow[t]{2}{*}{12} & $\mathrm{Ca}$ & 40,38 & 34,10 & 8,43 & 17,08 \\
\hline & B & 34,93 & 45,43 & 4,90 & 14,73 \\
\hline
\end{tabular}


Tabela 18 - Distribuição porcentual das quantidades de cálcio e boro acumuladas nas partes das plantas de girassol do híbrido Rumbossol-91. Média de quatro repetições.

\begin{tabular}{|c|c|c|c|c|c|}
\hline \multirow[b]{2}{*}{ Tratamentos } & \multirow[b]{2}{*}{ Nutrientes } & \multicolumn{4}{|c|}{ Parte da Planta } \\
\hline & & $\begin{array}{c}\text { Folhas } \\
\text { superiores }\end{array}$ & $\begin{array}{c}\text { Folhas } \\
\text { inferiores }\end{array}$ & $\begin{array}{c}\text { Caules } \\
\text { superiores }\end{array}$ & $\begin{array}{c}\text { Caules } \\
\text { Inferiores }\end{array}$ \\
\hline \multirow[t]{2}{*}{1} & $\mathrm{Ca}$ & 43,82 & 38,80 & 5,95 & 11,42 \\
\hline & $\mathrm{B}$ & 41,29 & 29,68 & 10,75 & 18,27 \\
\hline \multirow[t]{2}{*}{2} & $\mathrm{Ca}$ & 34,36 & 40,30 & 6,92 & 18,41 \\
\hline & $\mathrm{B}$ & 51,66 & 30,00 & 6,59 & 11,74 \\
\hline \multirow[t]{2}{*}{3} & $\mathrm{Ca}$ & 53,61 & 23,61 & 7,89 & 14,88 \\
\hline & $\mathrm{B}$ & 46,17 & 28,73 & 10,49 & 14,60 \\
\hline \multirow[t]{2}{*}{4} & $\mathrm{Ca}$ & 31,05 & 39,70 & 6,61 & 22,63 \\
\hline & B & 44,74 & 40,87 & 4,95 & 9,43 \\
\hline \multirow[t]{2}{*}{5} & $\mathrm{Ca}$ & 56,16 & 27,39 & 5,98 & 10,46 \\
\hline & $\mathrm{B}$ & 35,10 & 29,85 & 13,91 & 21,12 \\
\hline \multirow[t]{2}{*}{6} & $\mathrm{Ca}$ & 44,23 & 33,24 & 6,05 & 16,47 \\
\hline & B & 53,94 & 33,93 & 4,41 & 7,70 \\
\hline \multirow[t]{2}{*}{7} & $\mathrm{Ca}$ & 63,09 & 23,70 & 5,50 & 7,70 \\
\hline & $\mathrm{B}$ & 34,22 & 28,58 & 9,74 & 27,44 \\
\hline \multirow[t]{2}{*}{8} & $\mathrm{Ca}$ & 45,71 & 36,96 & 6,46 & 10,86 \\
\hline & B & 37,87 & 41,09 & 7,16 & 13,87 \\
\hline \multirow[t]{2}{*}{9} & $\mathrm{Ca}$ & 57,36 & 29,29 & 4,95 & 8,39 \\
\hline & $\mathrm{B}$ & 45,79 & 29,84 & 8,39 & 15,97 \\
\hline \multirow[t]{2}{*}{10} & $\mathrm{Ca}$ & 46,14 & 34,91 & 5,90 & 13,04 \\
\hline & $\mathrm{B}$ & 37,23 & 43,94 & 5,16 & 13,66 \\
\hline \multirow[t]{2}{*}{11} & $\mathrm{Ca}$ & 61,33 & 27,59 & 4,71 & 6,35 \\
\hline & $\mathrm{B}$ & 39,96 & 28,14 & 9,01 & 22,87 \\
\hline \multirow[t]{2}{*}{12} & $\mathrm{Ca}$ & 40,07 & 40,80 & 5,43 & 13,68 \\
\hline & B & 33,52 & 39,07 & 6,10 & 21,29 \\
\hline
\end{tabular}

As porcentagens de cálcio e boro foram maiores nas folhas superiores, seguidas pelas folhas inferiores, caules inferiores e por último pelos caules superiores.

Os resultados sugerem que a distribuição do boro no interior das plantas de girassol é principalmente influenciada pela transpiração, permitindo acúmulo maior nas regiões finais da cadeia transpiratória. 


\section{CONCLUSÕES}

Considerando-se as condições em que foi conduzido o experimento, os resultados permitiram concluir que:

- a manifestação de sintomas visuais de deficiência de boro foi mais intensa no cultivar IAC-Uruguai, no tratamento com $0,1 \mathrm{mg} \mathrm{L}^{-1}$ de B;

- o aumento da concentração de cálcio na solução nutritiva favoreceu o desenvolvimento das plantas de girassol;

- as quantidades totais de macronutrientes acumulados pelas plantas de girassol dos dois cultivares obedeceram à seguinte ordem: $\mathrm{K}>\mathrm{N}>\mathrm{Ca}>\mathrm{Mg}>\mathrm{P}>\mathrm{S}$;

- as quantidades totais de micronutrientes acumulados pelas plantas de girassol dos dois cultivares obedeceram à seguinte ordem: $\mathrm{Fe}>\mathrm{Mn}>\mathrm{B}>\mathrm{Zn}>\mathrm{Cu}$.

- o acúmulo de cálcio na parte aérea das plantas de girassol dos dois cultivares aumentou com o incremento das doses de cálcio na solução nutritiva;

- o acúmulo de cálcio na parte aérea das plantas de girassol foi maior no tratamento em que foi fornecido a maior dose de boro;

- as folhas acumularam maior quantidade de cálcio e boro do que os caules;

- a dose de $200 \mathrm{mg} \mathrm{L}^{-1}$ de Ca na solução nutritiva não foi a que propiciou a máxima produção de matéria seca da parte aérea das plantas de girassol;

- o maior acúmulo de boro e cálcio nas folhas evidenciou a baixa mobilidade de redistribuição desses nutrientes das plantas de girassol. 


\section{REFERÊNCIAS BIBLIOGRÁFICAS}

AGRIANUAL 99. FNP Consultoria \& Comércio. Ed. Argos, p.327-330, 1999.

BATAGLIA, O. C.; FURLANI, A. M. C.; TEIXEIRA, J. P. F.; FURLANI, P. R.; GALLO, J. R. Métodos de análise química de plantas. Boletim técnico, IAC, n.78, 48p., 1983.

BAUMGARTNER, J. G.; ANDREATTA, J. A.; FORMIGONI Jr., A. Efeitos da deficiência de cálcio e/ou boro sobre o pedúnculo do capítulo de girassol. Pesquisa Agropecuária Brasileira, v.27, p.739-746, 1986.

BLAMEY, F. P. C.; VERMUELEN, W. J.; CHAPMAN, J. Inheritance of boron status in sunflower. Crop Science, v.24, p.43-46, 1984.

BLAMEY, F. P. C.; EDWARDS, D. G.; ASHER, C. J. Nutricional Disorders of Sunflower. Queensland: Department of Agriculture, University of Queensland, 1987. $72 \mathrm{p}$.

BROWN, P. H.; HU, H. Boron uptake by sunflower, squash and cultured tobacco cells. Physiologia Plantarum, v.91, p.435-441, 1994.

BROWN, P. H.; HU, H. Phloem mobility of boron is species dependent: evidence for plhoem mobility in sorbitol-rich species. Annals of Botany, v.77, p.497-505, 1996. 
BROWN, P. H.; SHELP, B. J. Boron mobility in plants. Plant and Soil, v.193, p.85$101,1997$.

BROWN, P. H.; BELLALOUI, N.; HU, H.; DANDEKAR, A. Transgenically enhanced sorbitol synthesis facilitates phloem boron transport and increases tolerance of tobacco to boron deficiency. Plant Physiology, v.119, p.17-20, 1999.

CAKMAK, I.; RÖMHELD, V. Boron deficiency-induced impairments of cellular functions in plants. Plant and Soil, v.193, p.71-83, 1997.

DANNEL, F.; PFEFFER, H.; RÖMHELD, V. Distribution within the plant or compartmentation does not contribute substantially to the detoxification of excess boron in sunflower (Helianthus annuus). Australian Journal of Plant Physiology, v.26, p.95-99, 1999.

DRAKE, M.; SIELING, D. H.; SCARSETH, G. D. Calcium-boron ratio as an important factor in controlling the boron starvation of plants. Journal of American Society of Agronomy, v.33, p.454-462, 1941.

EPSTEIN, E. Nutrição mineral das plantas: princípios e perspectivas. Rio de Janeiro: Livros Técnicos e Científicos, 1975, 341p.

ESTEBAN, E.; CARPENA RUIZ, R. O.; GÁRATE, A. Boron and calcium distribution in B and Ca deficient pea plants. In: Bell, R. W.; Rerkasem, B. (Eds). Proceedings Netherlands: Kluwer Academic Publishers, 1997, p.187-190.

FOSTER, H.; MENGEL, K. The effect of a short termin terruption in thek supply during the early stage on yield formation, mineral content and soluble amino acid content. Zeitschrift fuer Ackerund. Pflanzenbau, n.130, p.203-213, 1969. 
FURlani, A. M. C.; ÚNGaro, M. R. G.; QUAGgiO, J. A. Comportamento diferencial de genótipos de girassol: Eficiência na absorção e uso do boro. Revista Brasileira de Ciência do Solo, v.14, p.187-194, 1990.

GUPTA, U. C.; MACLEOD, J. A. Influence of calcium and magnesium sources on boron uptake and yield of alfafa and rutabagas as related to soil $\mathrm{pH}$. Soil Science, v.124, p.279-284, 1977.

HILL, W. E.; MORRILL, L. G. Boron, calcium, and potassium interations in Spanish Peanuts. Soil Science Society of America Proceedings, v.39, p.80-83, 1975.

HU, H.; BROWN, P. H.; LABAVITCH, I. M. Species variability in boron requirement is correlated with cell wall pectin. Journal of Experimental Botany, v.47, p.227$232,1996$.

HU, H.; BROWN, P. H. Absorption of boron by plant roots. Plant and Soil, v.193, p.49-58, 1997.

KOHL, H. C.; OERTLI, J. J. Distribution of boron in leaves. Plant Physiology, v.36, p.420-424, 1961.

MALAVOLTA, E. Elementos de nutrição mineral de plantas. S. Paulo: Ed Ceres, $1980,251 \mathrm{p}$.

MARSCHNER, H. Mineral nutrition of higher plants. London: Academic Press, $1995.889 \mathrm{p}$.

MENGEL, K. ; KIRKBY, E. A. Principles of plant nutrition. 4 ed. Bern, International Potash Institute, $1987.655 \mathrm{p}$. 
NABLE, R. O. Resistance to boron toxicity amongst several barley wheat cultivars: A preliminary examination of the resistance mechanism. Plant and Soil, v.112, p.4552, 1988 .

OYEWOLE, O. I.; ADUAYI, E. A. Evoluation of the growth and quality of the "Ife plum" tomato as affected by boron and calcium fertilization. Journal of Plant Nutrition, v.15, p.199-209, 1992.

PFEFFER, H.; DANNEL, F.; RÖMHELD, V. Compartmentation of boron in roots and its translocation to the shoot of sunflower as affected by short term changes in boron supply. In: Bell, R. W.; Rerkasem, B. (Eds). Proceedings Netherlands: Kluwer Academic Publishers, 1997 p.203-207.

PLESE, L. P. M.; TIRITAN, C. S.; YASSUDA, E. I.; PROCHNOW, L. I.; CORRENTE, J. E; MELLO, S. C. Efeitos das aplicações de cálcio e de boro na ocorrência de podridão apical e produção de tomate em estufa. Scientia Agricola, v.55, p.144-148, 1998.

QUAGGIO, J. A.; SILVA, N. M.; BERTON, R. S. Micronutrientes na agricultura. In: FERREIRA, M. E. IN: SIMPÓSIO SOBRE MICRONUTRIENTES NA AGRICULTURA, 1., Jaboticabal, 1988. Piracicaba: POTAFÓS/CNPq, 1991. 734p.

RAVEN, J. A. Short - and long - distance transport of boric acid in plants. New Phytologist. v.84, p.231-249, 1980.

REEVE, E.; SHIVE, J. W. Potassium-boron and calcium-boron relationships in plant nutrition. Soil Science, v.57, p.1-14, 1944.

ROSSI, R. O. Girassol. Curitiba: Ed. Tecnoagro. 1998. 333p. 
SANTOS, I.S.; BARBEADO, C. J.; PIPITAI, R.; FERREIRA, S. M.; NAKAGAWA, J. Estudo da relação Ca x B na cultura do pimentão. Horticultura Brasileira, v.8, p.1923, 1990.

SARRUGE, J. R.; HAAG, H. P. Análise química em plantas. Piracicaba: ESALQ, 1974. 56p.

SARRUGE, J. R. Soluções nutritivas. Summa Phytopathologica, v.1, n.3, p.231-233, 1975.

SAS INSTITUTE. The SAS-system for windows: release 6.11 (software). Cary, 1996.

SERESINHE, P. S.; OERTLI, J. J. Effects of boron on growth of tomato cell suspensions. Physiologia Plantarum, v.81, p.31-36, 1991.

SFREDO, G. J.; SARRUGE, J. R.; HAAG, H. P.(b) Absorção de nutrientes por duas cultivares de girassol (Helianthus annus L.), em condições de campo. III. Acúmulo de macronutrientes. Anais da Escola Superior de Agricultura “Luiz de Queiroz", Piracicaba, v.40, p.1189-1218, 1983.

SFREDO, G. J.; SARRUGE, J. R.; HAAG, H. P.(a) Absorção de nutrientes por duas cultivares de girassol (Helianthus annus L.), em condições de campo. IV. Acúmulo de micronutrientes. Anais da Escola Superior de Agricultura "Luiz de Queiroz", Piracicaba, v.40, p.1219-1245, 1983.

SFREDO, G. J. Absorção de nutrientes por duas cultivares de girassol (Helianthus annuus) em condições de campo. Piracicaba, 1984. 99 p. Tese (Doutorado) - Escola Superior de Agricultura "Luiz de Queiroz", Universidade de São Paulo. 
SFREDO, G. J.; SARRUGE, J. R. Concentração de micronutrientes em órgãos de plantas de girassol. Pesquisa Agropecuária Brasileira, v.25, p.1727-1732, 1990.

SHELP, B. J.; MARENTES, E.; KITHEKA, A. M.; VIVEKANANDAN, P. Boron mobility in plants. Physiologia Plantarum, v.94, p.356-361, 1995.

SILVA, M. N. da. A cultura do girassol. Jaboticabal: FUNEP, 1990. 67p.

UNGARO, M. R. G. Cultura do girassol. Campinas, Instituto Agronômico, 2000. 36p. (Boletim técnico, 188).

VRANCEANU, A. V. El girassol. Madrid: Ediciones Mundi-Prensa, 1977. 379p.

YAMAUCHI, T.; HARA, T.; SONODA, Y. Distribution of calcium and boron in the pectin fraction of tomato leaf cell wall. Plant and Cell Physiology, v.27, p.729-732, 1986. 
ANEXOS 
Tabela A - Valores de temperatura tomados na casa-de-vegetação durante o período experimental.

\begin{tabular}{|c|c|c|c|}
\hline \multirow[t]{3}{*}{ DATA } & \multicolumn{3}{|c|}{ Temperatura } \\
\hline & Máxima & Mínima & Média \\
\hline & \multicolumn{3}{|c|}{ - } \\
\hline $08 / 04 / 2000$ & 40,0 & 21,5 & 30,75 \\
\hline $09 / 04 / 2000$ & 40,0 & 21,5 & 30,75 \\
\hline $10 / 04 / 2000$ & 40,0 & 22,0 & 31,00 \\
\hline $11 / 04 / 2000$ & 40,0 & 20,5 & 30,25 \\
\hline $12 / 04 / 2000$ & 39,5 & 20,5 & 30,00 \\
\hline $13 / 04 / 2000$ & 37,5 & 21,5 & 29,50 \\
\hline $14 / 04 / 2000$ & 39,0 & 22,0 & 30,50 \\
\hline $15 / 04 / 2000$ & 37,0 & 20,0 & 28,50 \\
\hline $16 / 04 / 2000$ & 37,0 & 19,0 & 28,00 \\
\hline $17 / 04 / 2000$ & 37,0 & 19,0 & 28,00 \\
\hline $18 / 04 / 2000$ & 33,0 & 26,0 & 29,50 \\
\hline $19 / 04 / 2000$ & 35,0 & 19,0 & 27,00 \\
\hline $20 / 04 / 2000$ & 36,0 & 17,0 & 26,50 \\
\hline $21 / 04 / 2000$ & 36,0 & 16,0 & 26,00 \\
\hline $22 / 04 / 2000$ & 36,5 & 16,0 & 26,25 \\
\hline $23 / 04 / 2000$ & 36,5 & 16,5 & 26,50 \\
\hline $24 / 04 / 2000$ & 36,0 & 17,0 & 26,50 \\
\hline $25 / 04 / 2000$ & 36,5 & 16,0 & 26,25 \\
\hline $26 / 04 / 2000$ & 37,0 & 17,0 & 27,00 \\
\hline $27 / 04 / 2000$ & 36,5 & 16,5 & 26,50 \\
\hline $28 / 04 / 2000$ & 36,0 & 17,0 & 26,50 \\
\hline $29 / 04 / 2000$ & 37,0 & 16,5 & 26,75 \\
\hline $30 / 04 / 2000$ & 36,5 & 16,0 & 26,25 \\
\hline $01 / 05 / 2000$ & 36,0 & 16,5 & 26,25 \\
\hline $02 / 05 / 2000$ & 37,0 & 18,0 & 27,5 \\
\hline $03 / 05 / 2000$ & 38,0 & 19,0 & 28,5 \\
\hline $04 / 05 / 2000$ & 38,5 & 20,0 & 29,25 \\
\hline $05 / 05 / 2000$ & 37,0 & 17,0 & 27,00 \\
\hline $06 / 05 / 2000$ & 37,5 & 18,0 & 27,75 \\
\hline $07 / 05 / 2000$ & 37,0 & 17,0 & 27,00 \\
\hline $08 / 05 / 2000$ & 36,0 & 19,0 & 27,50 \\
\hline $09 / 05 / 2000$ & 33,0 & 20,0 & 26,50 \\
\hline $10 / 05 / 2000$ & 36,0 & 16,0 & 26,00 \\
\hline $11 / 05 / 2000$ & 32,0 & 16,0 & 24,00 \\
\hline $12 / 05 / 2000$ & 35,0 & 14,0 & 24,50 \\
\hline $13 / 05 / 2000$ & 35,5 & 16,0 & 25,75 \\
\hline $14 / 05 / 2000$ & 35,0 & 15,0 & 25,00 \\
\hline
\end{tabular}




\begin{tabular}{cccc}
\hline DATA & \multicolumn{3}{c}{ Temperatura } \\
\cline { 2 - 4 } & Máxima & Mínima & Média \\
\hline $15 / 05 / 2000$ & 35,0 & 16,0 & 25,50 \\
$16 / 05 / 2000$ & 35,0 & 16,0 & 25,50 \\
$17 / 05 / 2000$ & 34,0 & 15,0 & 24,50 \\
$18 / 05 / 2000$ & 34,0 & 14,0 & 24,00 \\
$19 / 05 / 2000$ & 33,0 & 14,0 & 23,50 \\
$20 / 05 / 2000$ & 34,0 & 16,0 & 25,00 \\
$21 / 05 / 2000$ & 32,0 & 13,0 & 22,50 \\
$22 / 05 / 2000$ & 35,5 & 13,5 & 24,50 \\
$23 / 05 / 2000$ & 35,0 & 15,0 & 25,00 \\
$24 / 05 / 2000$ & 34,0 & 16,0 & 25,00 \\
$25 / 05 / 2000$ & 34,0 & 16,0 & 25,00 \\
$26 / 05 / 2000$ & 36,0 & 16,0 & 26,00 \\
$27 / 05 / 2000$ & 35,0 & 16,0 & 25,50 \\
$28 / 05 / 2000$ & 33,0 & 11,0 & 22,00 \\
$29 / 05 / 2000$ & 33,5 & 11,0 & 22,25 \\
$30 / 05 / 2000$ & 33,0 & 12,0 & 22,50 \\
$31 / 05 / 2000$ & 32,0 & 11,0 & 21,50 \\
\hline
\end{tabular}

